University of Wollongong

Research Online

2013

Combining realism with rigour: evaluation of a national kitchen garden program in Australian primary schools

\author{
Heather Yeatman \\ University of Wollongong, hyeatman@uow.edu.au \\ Karen Quinsey \\ University of Wollongong, kquinsey@uow.edu.au \\ James Dawber \\ University of Wollongong, jpd551@uowmail.edu.au \\ W. Nielsen \\ University of Wollongong, wnielsen@uow.edu.au \\ Deanne Condon-Paoloni \\ University of Wollongong, deannecp@uow.edu.au
}

See next page for additional authors

Follow this and additional works at: https://ro.uow.edu.au/ahsri

Research Online is the open access institutional repository for the University of Wollongong. For further information contact the UOW Library: research-pubs@uow.edu.au 


\title{
Combining realism with rigour: evaluation of a national kitchen garden program in Australian primary schools
}

\author{
Abstract \\ Overview \\ - Background on Program \\ - Overview of evaluation framework \& methods \\ - Findings: Outcomes \\ - Findings: Program learning - Health Promoting Schools \\ - Questions

\section{Keywords} \\ combining, australian, schools, program, garden, kitchen, primary, national, evaluation, rigour, realism

\section{Publication Details} \\ H. Yeatman, K. Quinsey, J. Dawber, W. Nielsen, D. Condon-Paoloni, S. Eckermann, D. Morris, P. Grootemaat \\ \& D. Fildes "Combining realism with rigour: evaluation of a national kitchen garden program in Australian \\ primary schools", AES (Australasian Evaluation Society) 2013 International Conference, Brisbane, 4-6 Sep \\ 2013, (2013)

\section{Authors} \\ Heather Yeatman, Karen Quinsey, James Dawber, W. Nielsen, Deanne Condon-Paoloni, Simon Eckermann, \\ Darcy Morris, Pamela Grootemaat, and David Fildes
}



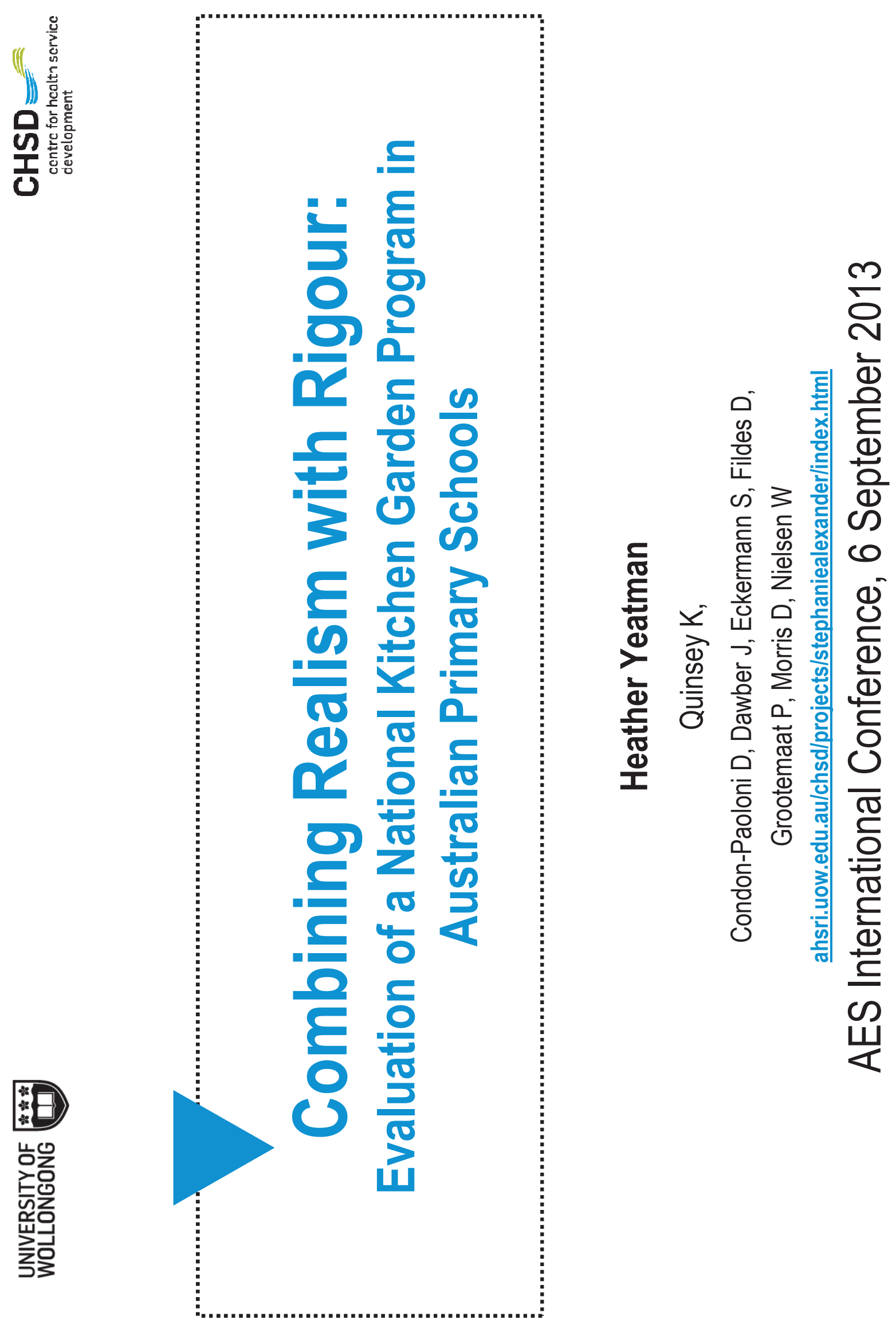

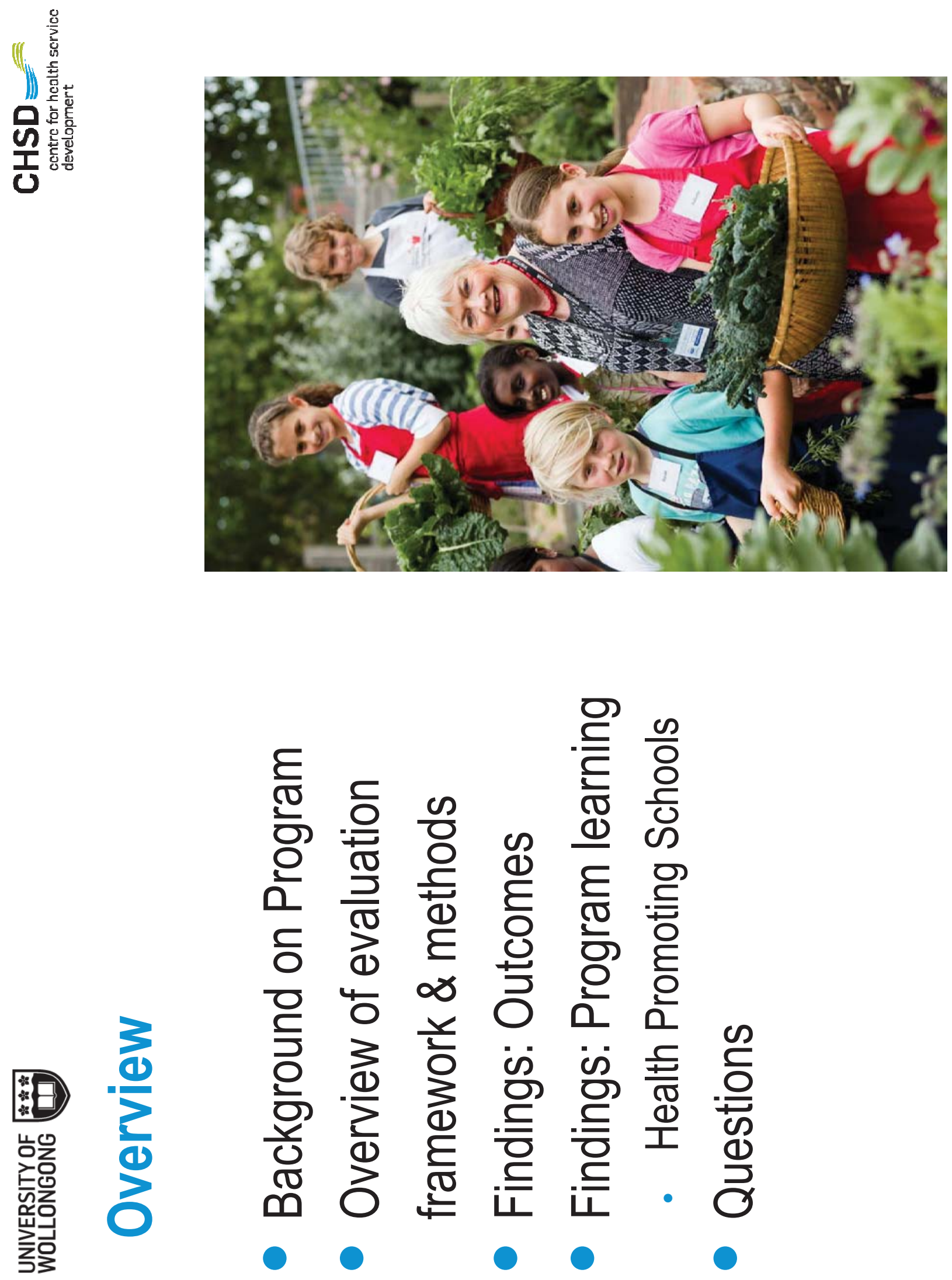

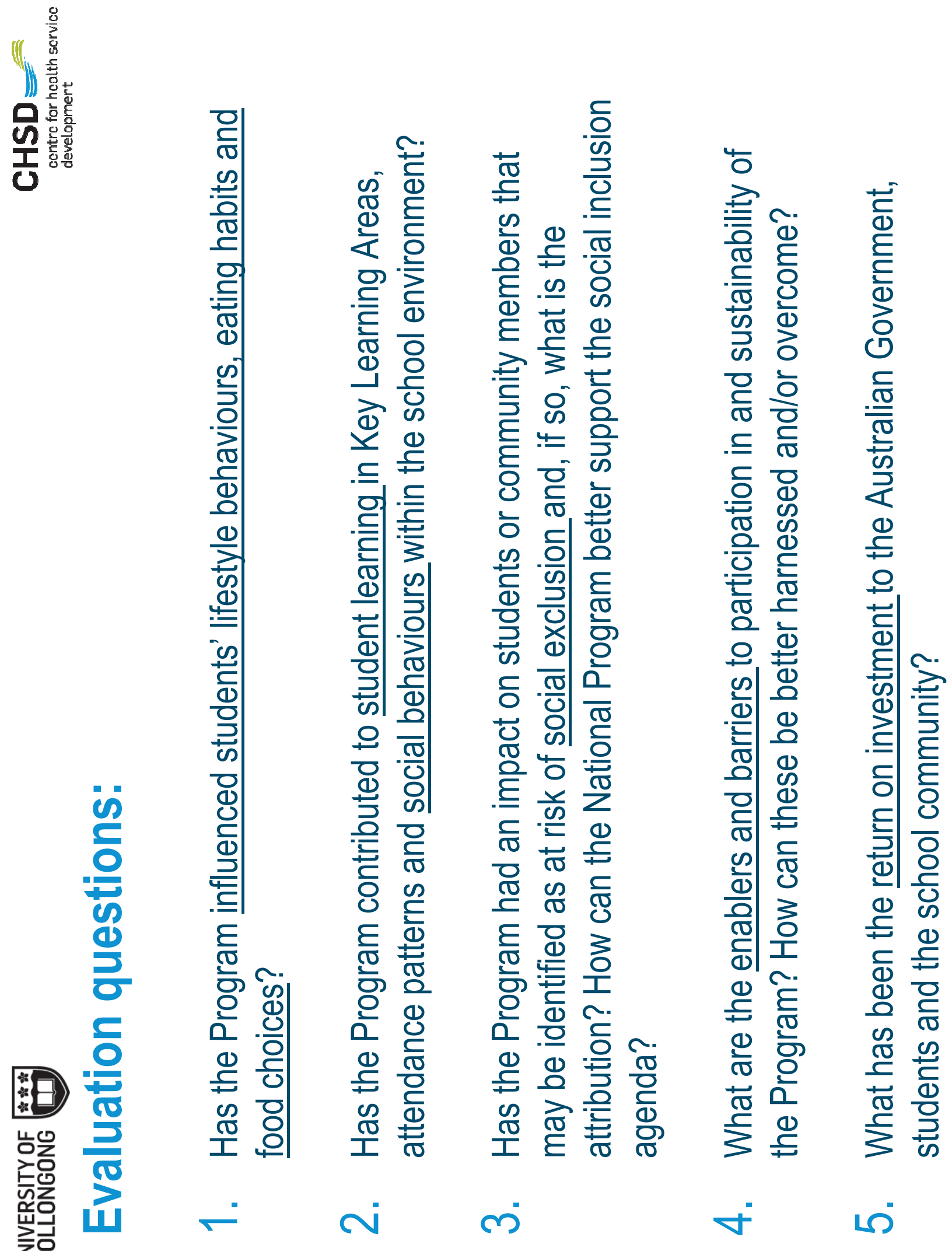


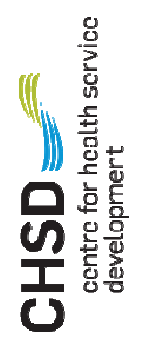

I

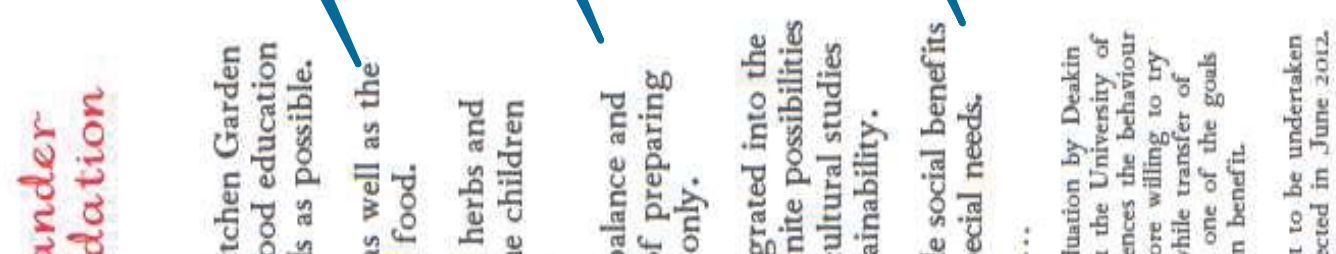

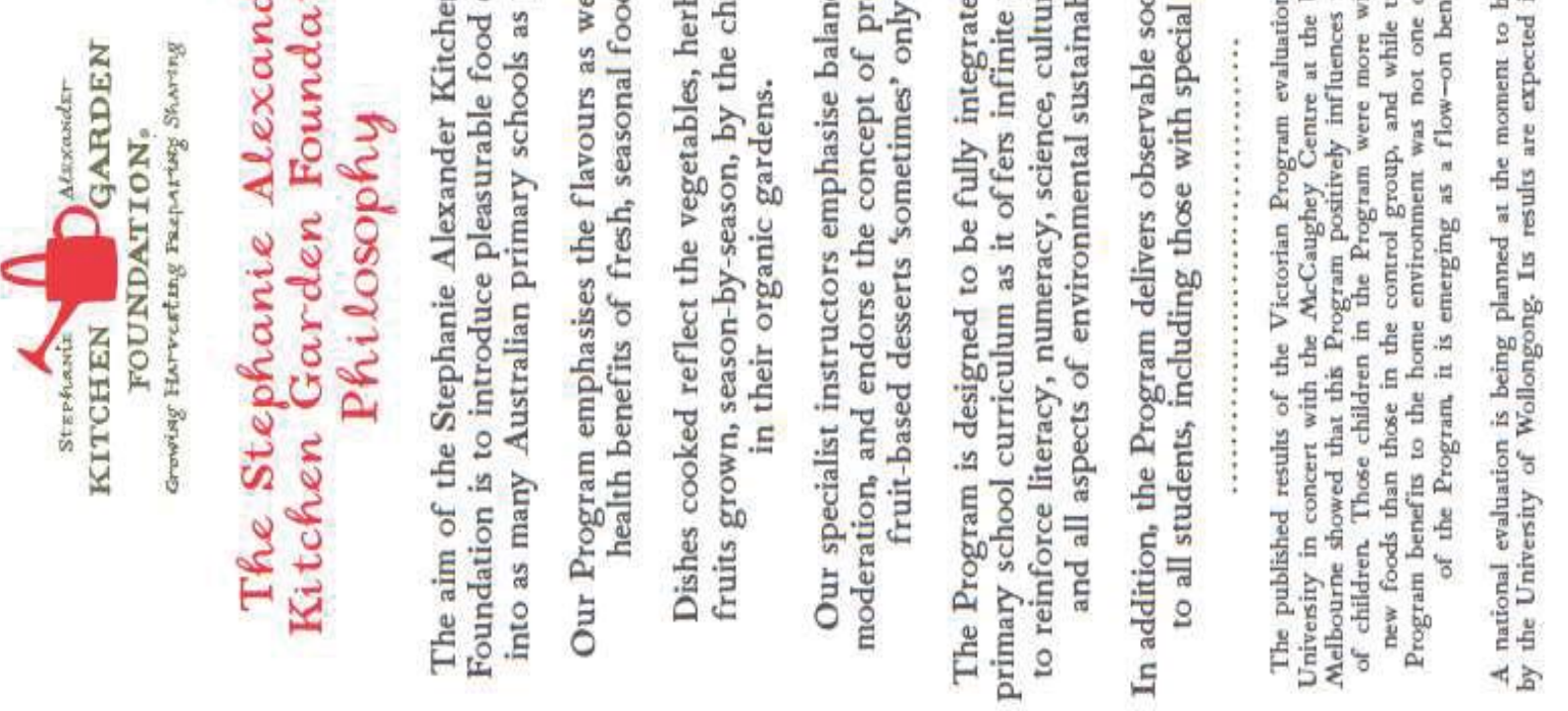
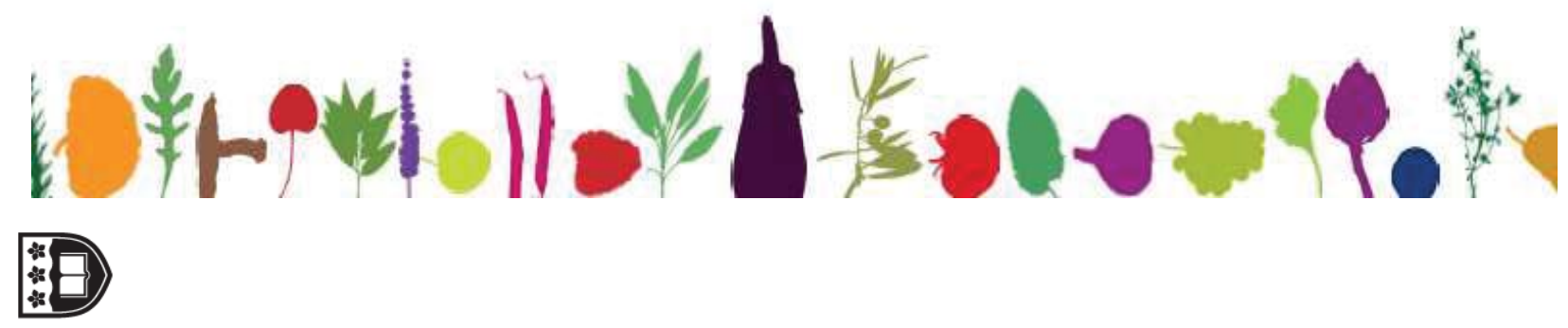

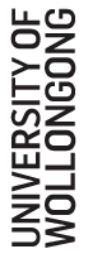




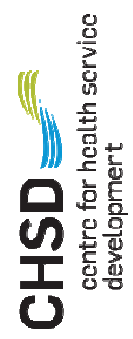

1

$\infty$

1

음

흐

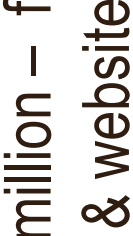

$\infty$ 이

N

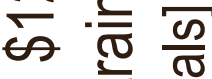

은 는

क्ष

ह
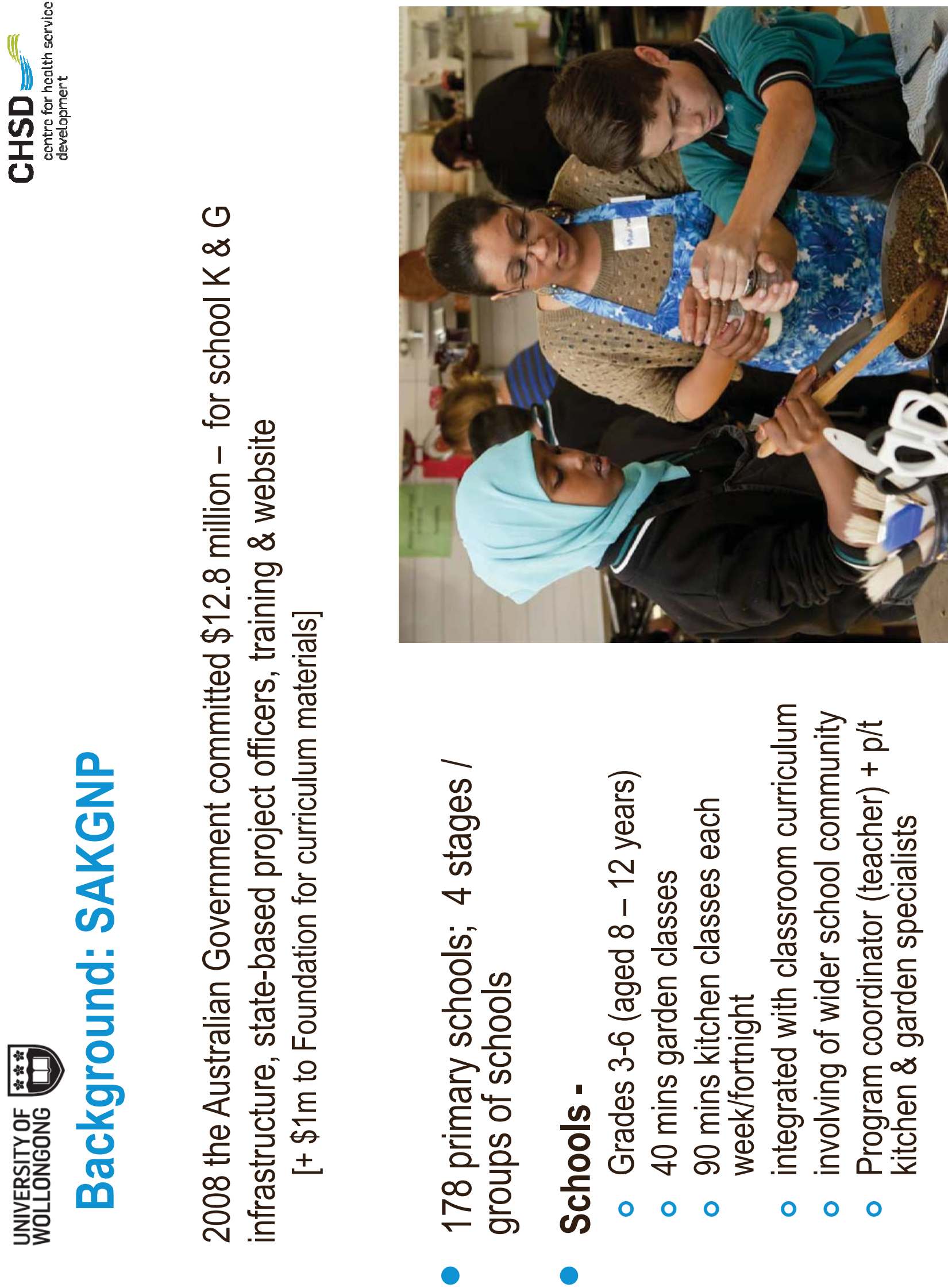

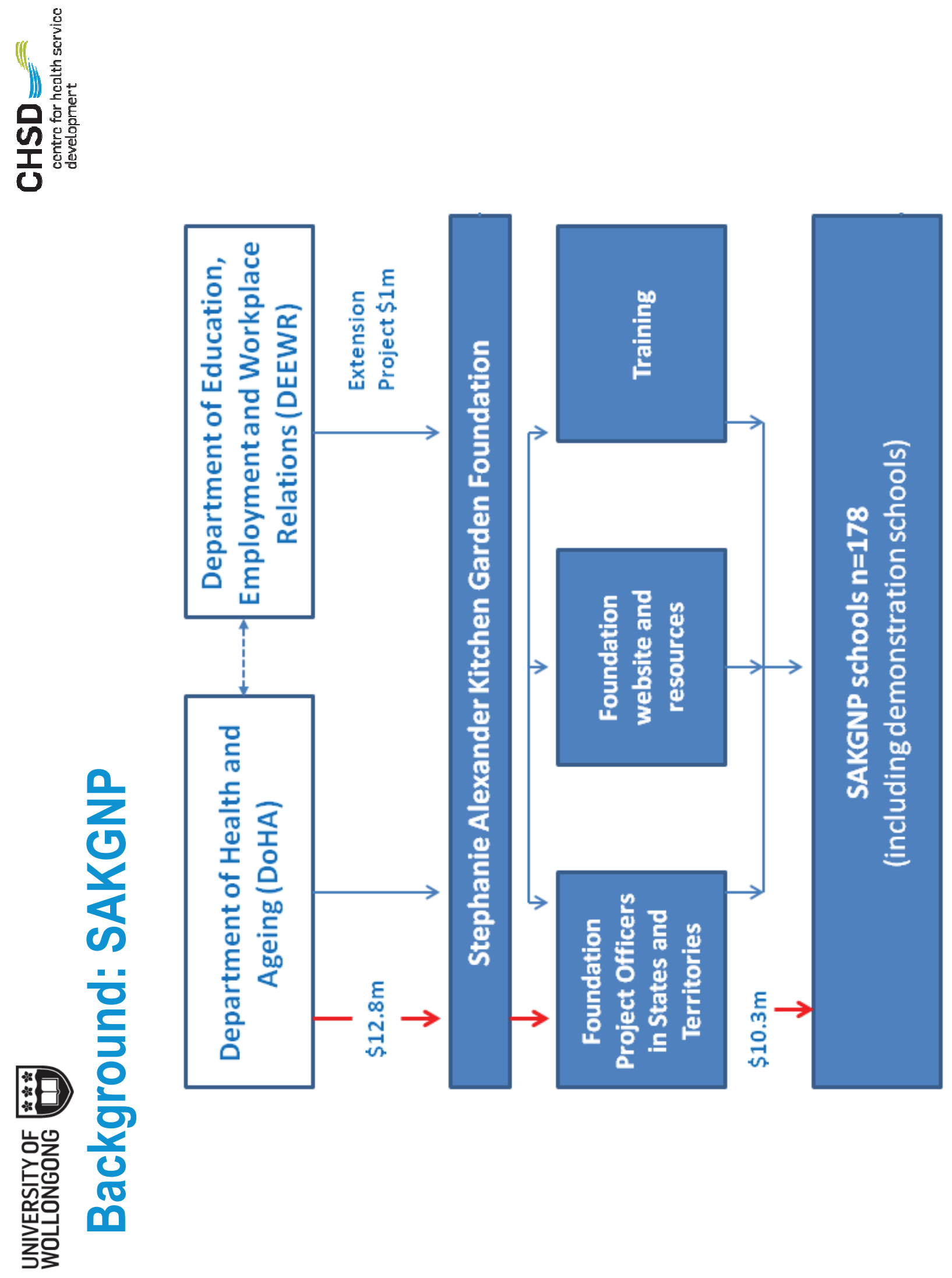

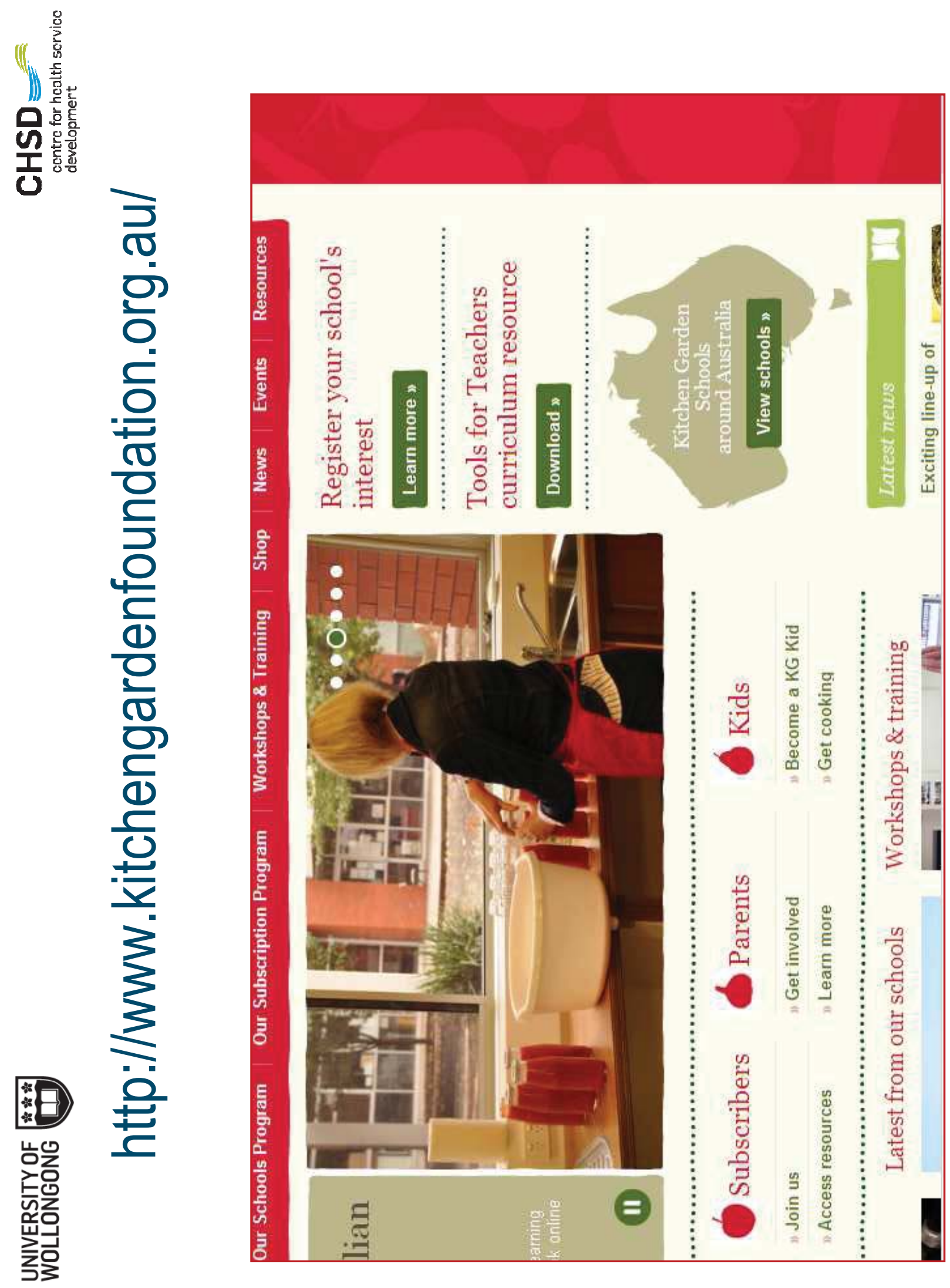

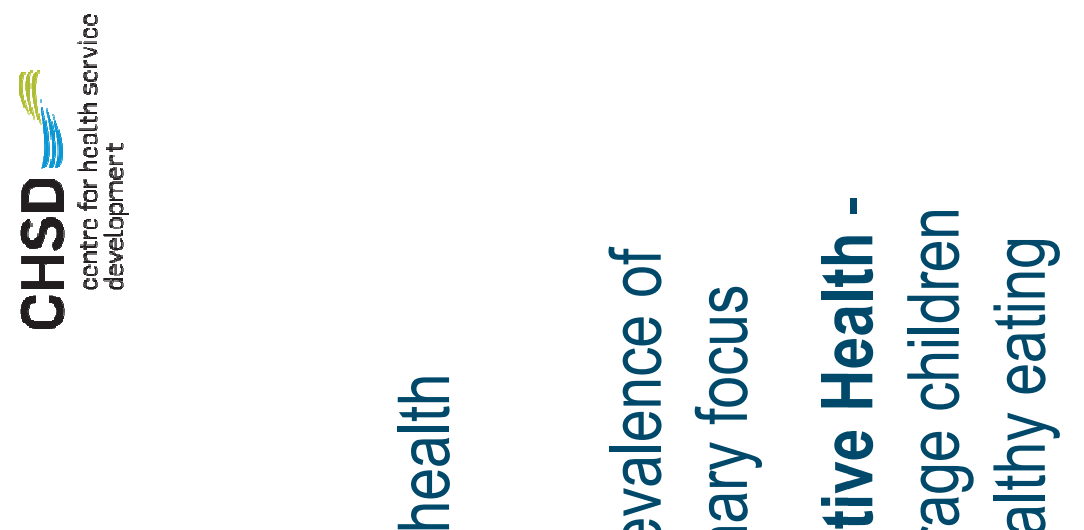

은

(1)

ع

4

잇

(1)

퉁

0

0

(9)

吾

$\stackrel{\text { I }}{\check{c}}$

ब ত্

두 응 흥 응

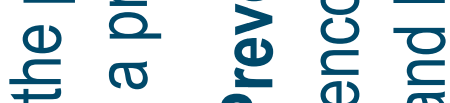

(1)

듬

$\subseteq \underline{\mathscr{\omega}}$

ด ฮิ ชิ

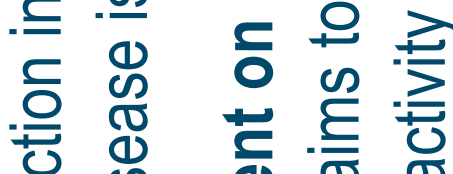

﨎

ชে

तত

ह

믕

늘

윤요

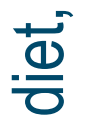

든 营

ฮั

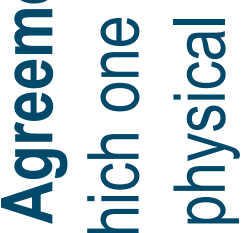

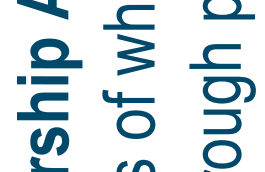

की 인

$\stackrel{\infty}{ \pm}$

t

ธ

西 $\frac{0}{2}$

六

造 0

$\overline{0}+$

등 ‘迹

은

을

के

त क

元

要

$2)^{\pi}$

응 또 뜌 휴

元 帘

오등 혹 는 은 은

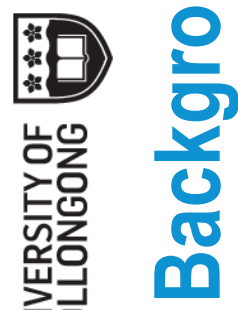

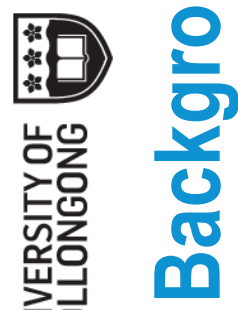

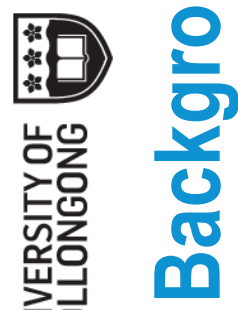

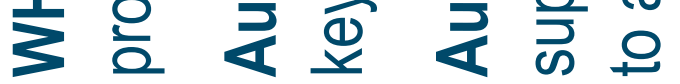

$\stackrel{\mathscr{C}}{\frac{\pi}{\sigma}}$

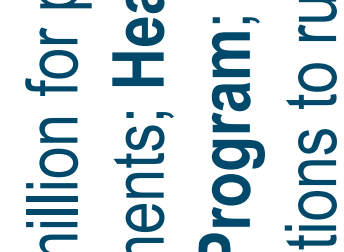

흔 츨 을 음

응 흥 ڤ

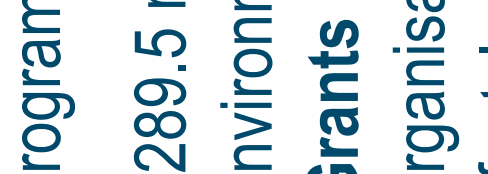

$\infty$ त

๙ 

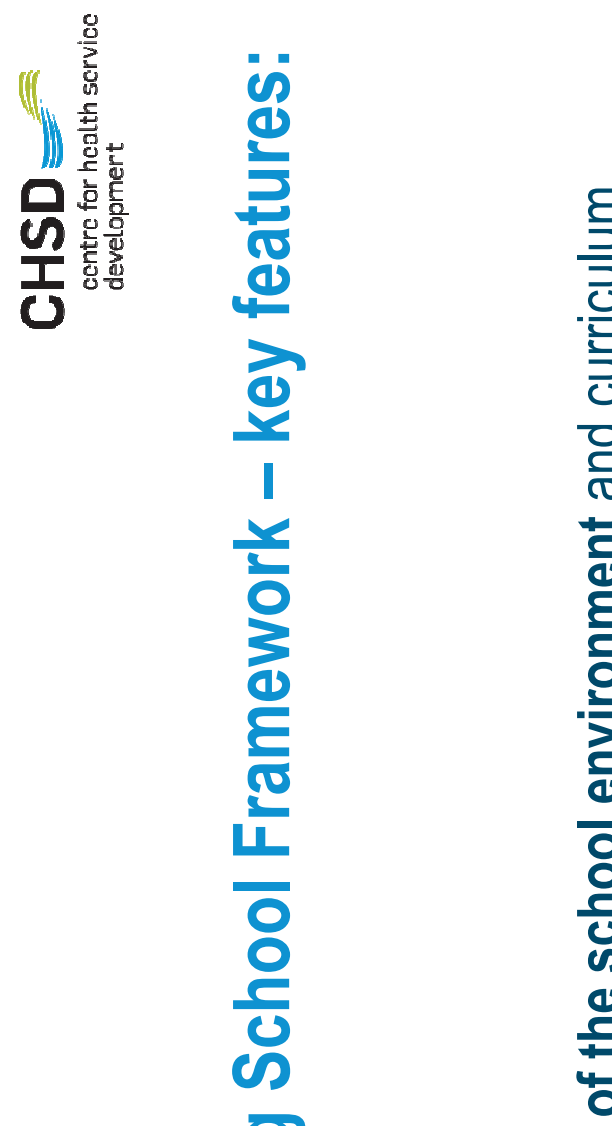

을

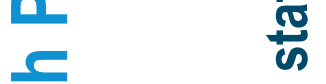

흐

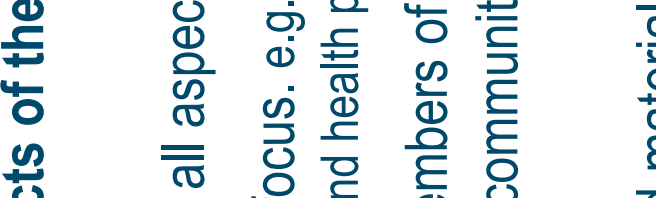

प)

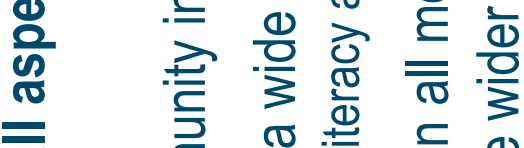

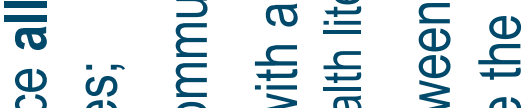

บุ

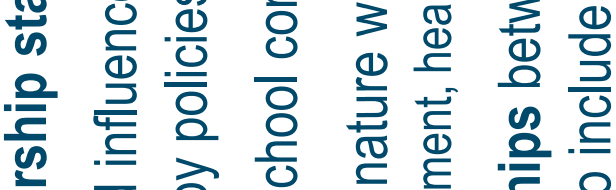

(1)

d)

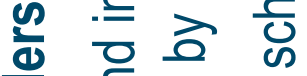

유 증 ब

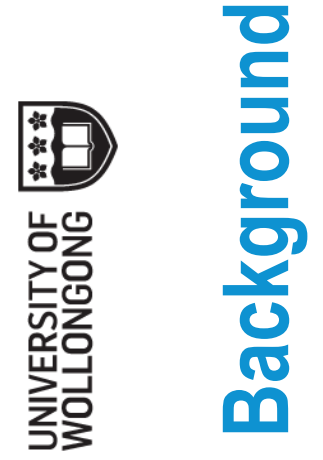

글 ڤ

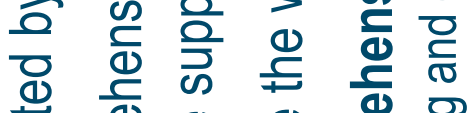

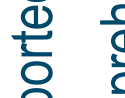

윽

(1)

क

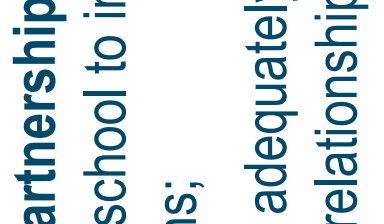

ণ

으

है

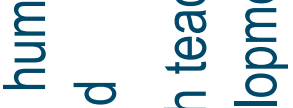

言

> क ष ठ

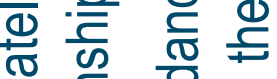

둥

으 응 응 이 드 은

은 응

홍

당

$\sum_{\substack{0 \\ 2}}^{\infty}$

$\frac{F}{\bar{\sigma}}$ 

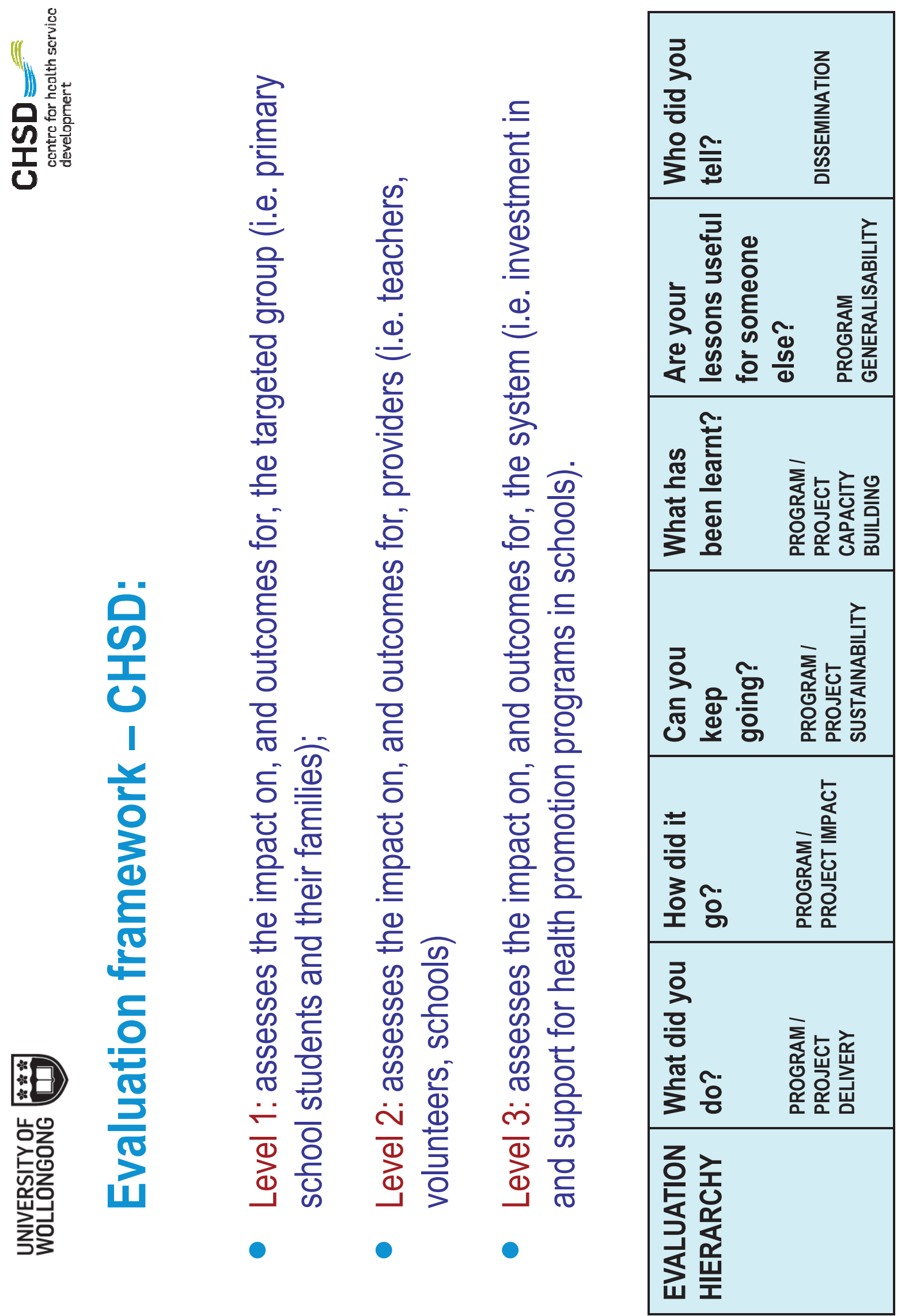


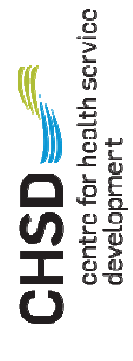

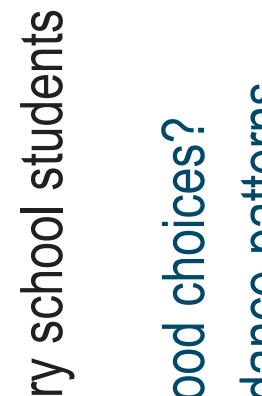

तั

틀 을 त

क का का का

里 完 ब

윽 응 눙

음

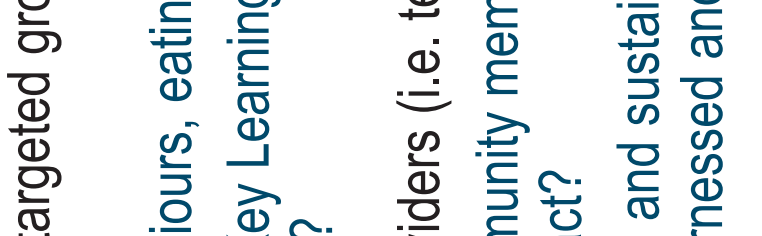

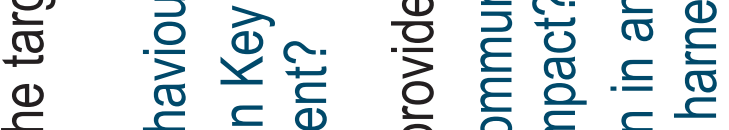

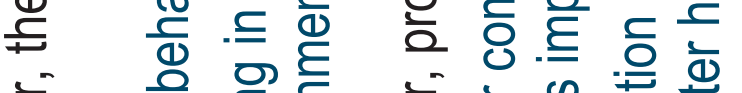

흐 ब을 을

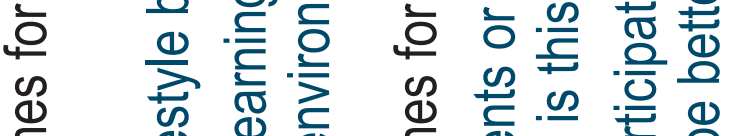

$\Phi$ क ष

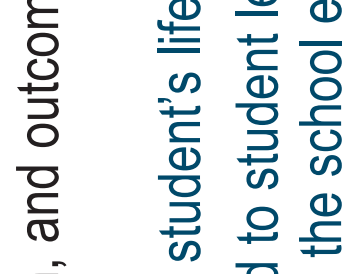

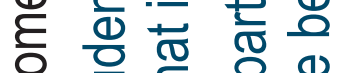

曾 严

응 ㅇํㅇ क्ञ

든 는 은

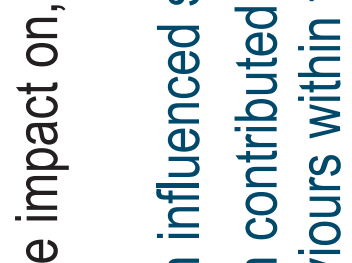

등 읕드 응 응

넝 드음 흔.

응 응

$\stackrel{\Phi}{\mp}$ ह $\frac{E}{0}$

(1) 든 음

Ф ह ख 응

क त़

ঋ

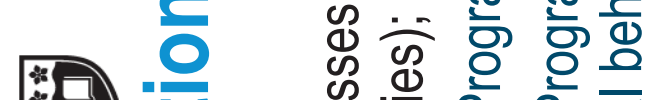

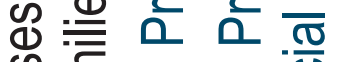

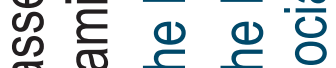

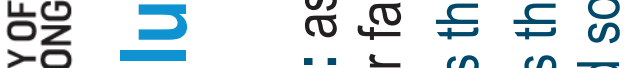

\&

की

袠

$\therefore$ 䨌 䒕

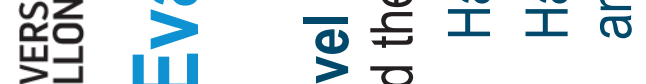

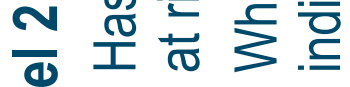

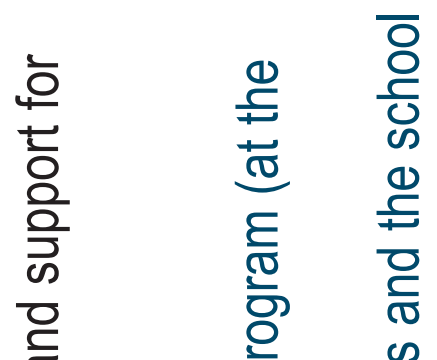

ㅎำ 을

志

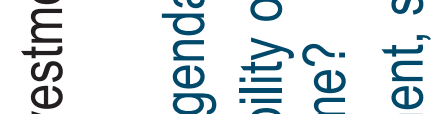

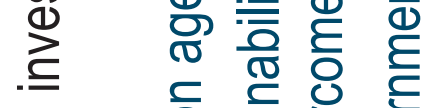

ㄹ.

क्षे

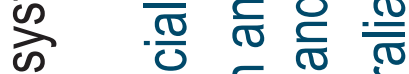

()

을 응 क

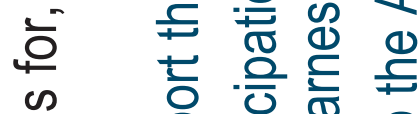

(1) 응 은 은

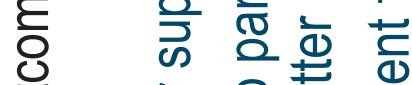

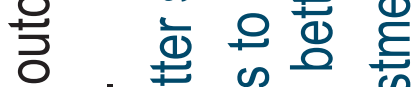

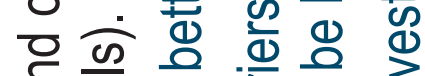

তั

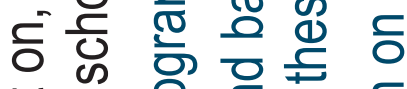

苑

हू है

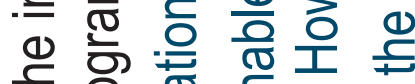

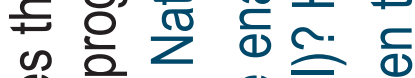

Ф)

网음

ભ

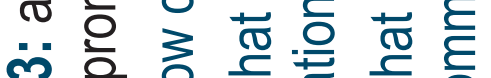

ब 0 ०

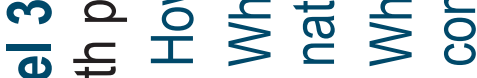

త্口 0 。

O 


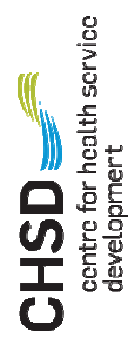

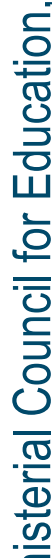

更

$\sum_{0}$

Ғ 난

능 닌

$\stackrel{\Phi}{E} \sum$

으 엉

बิ ल ल

든

这 冚

$\frac{2}{10}$

(1)

$\pi$

돈

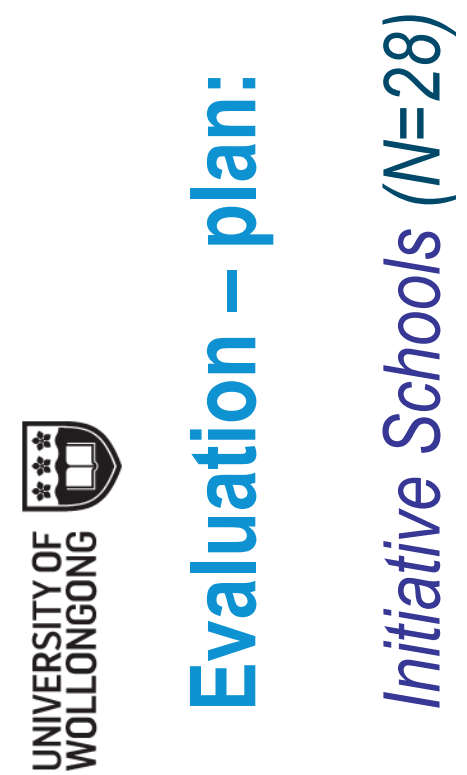

ఖ

ఖ ब

엉 흥 응

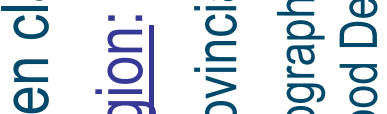

बiे

ש

ণ্তে

芩

을 을

ত ত 음

능 등

4

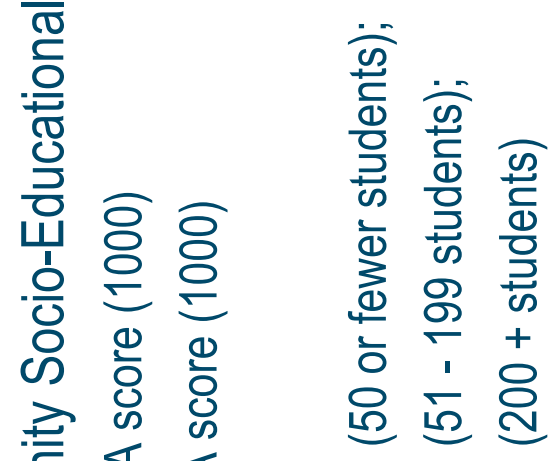

융 인 은

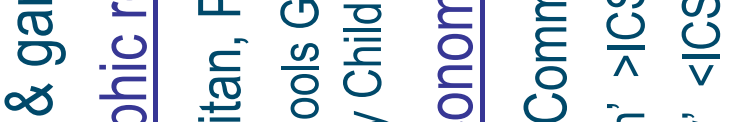

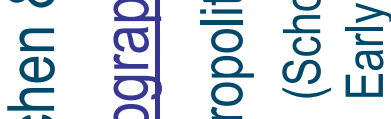

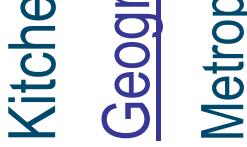

ปิ

0
प0
đิ
드

i़่

六 

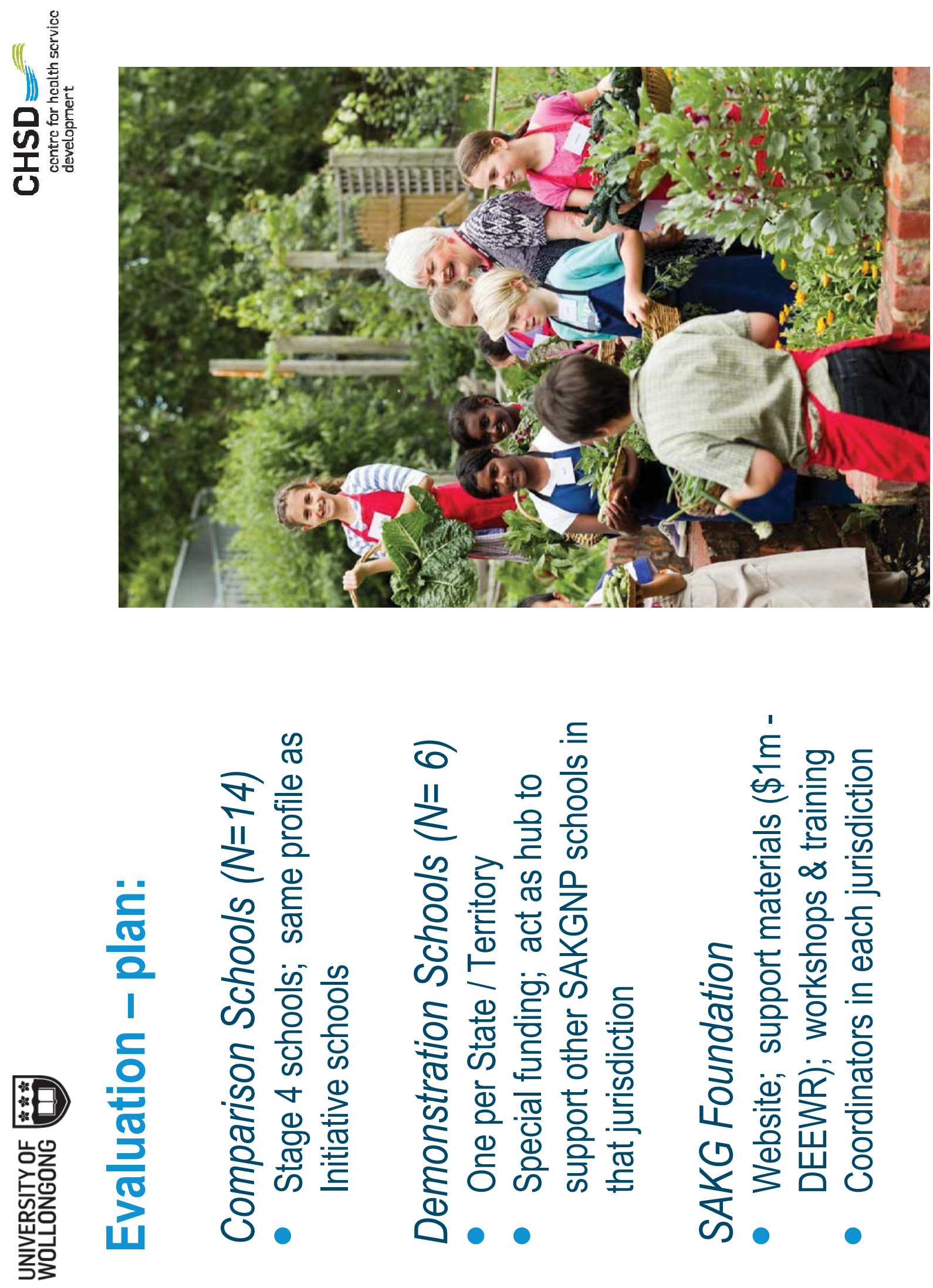


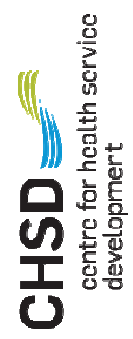

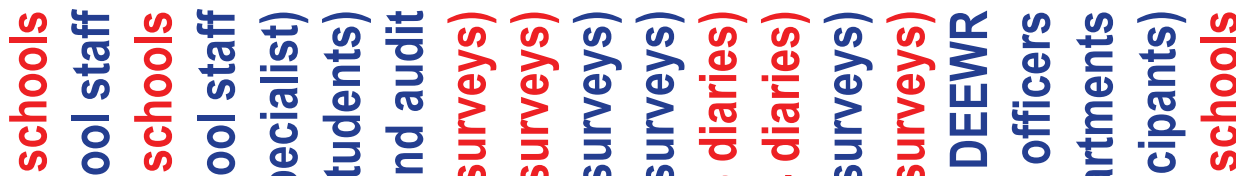

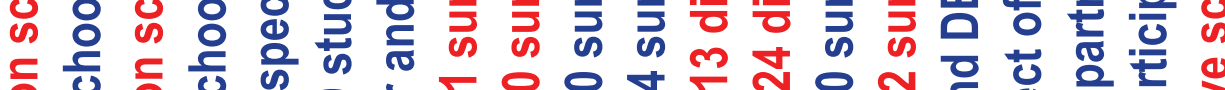

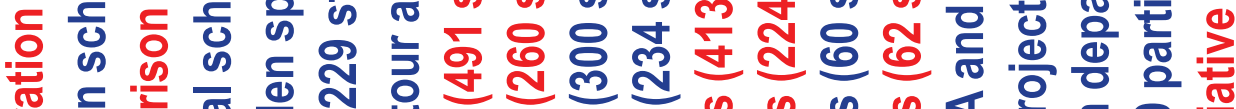

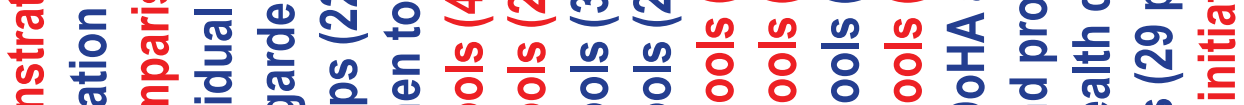

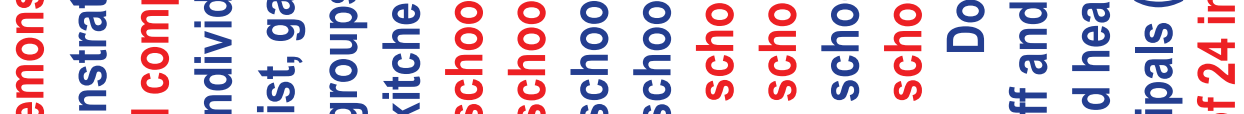
흥 응 드 흔 $\infty$ 등

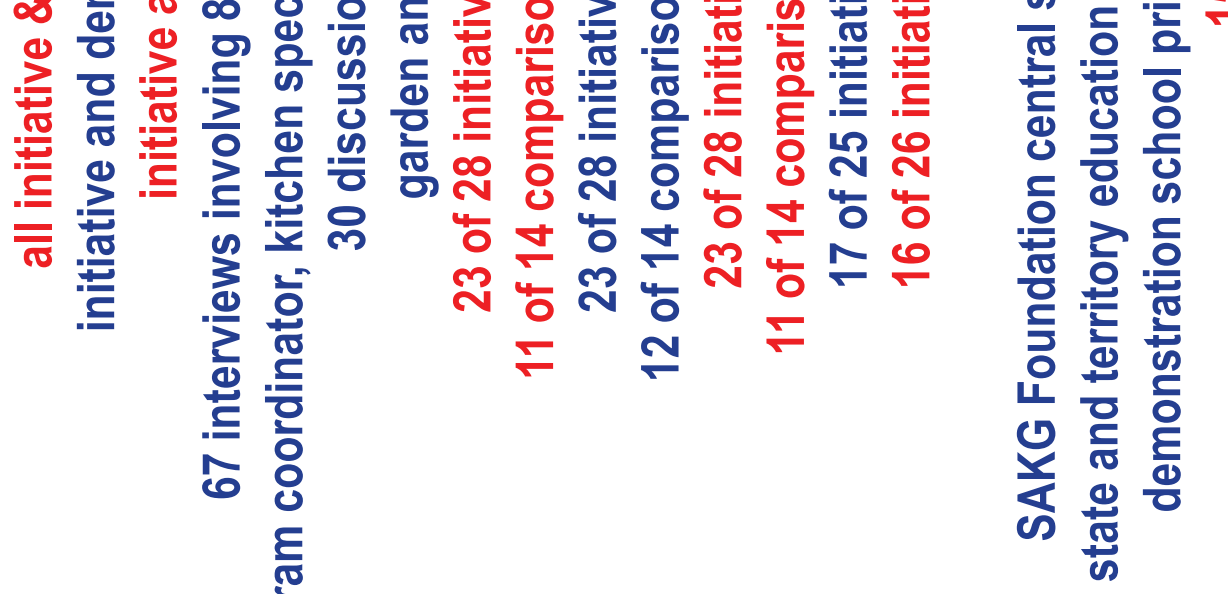

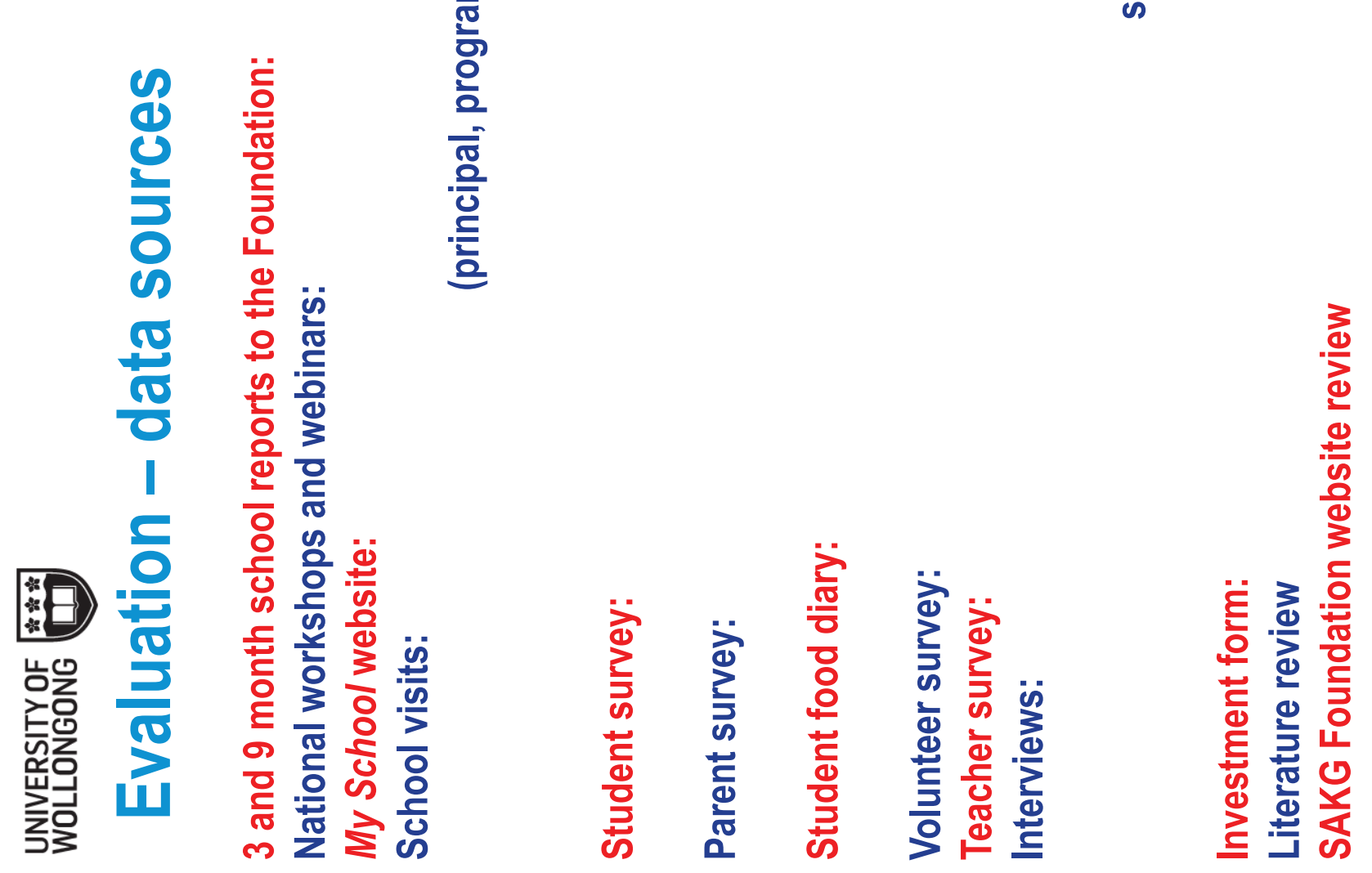



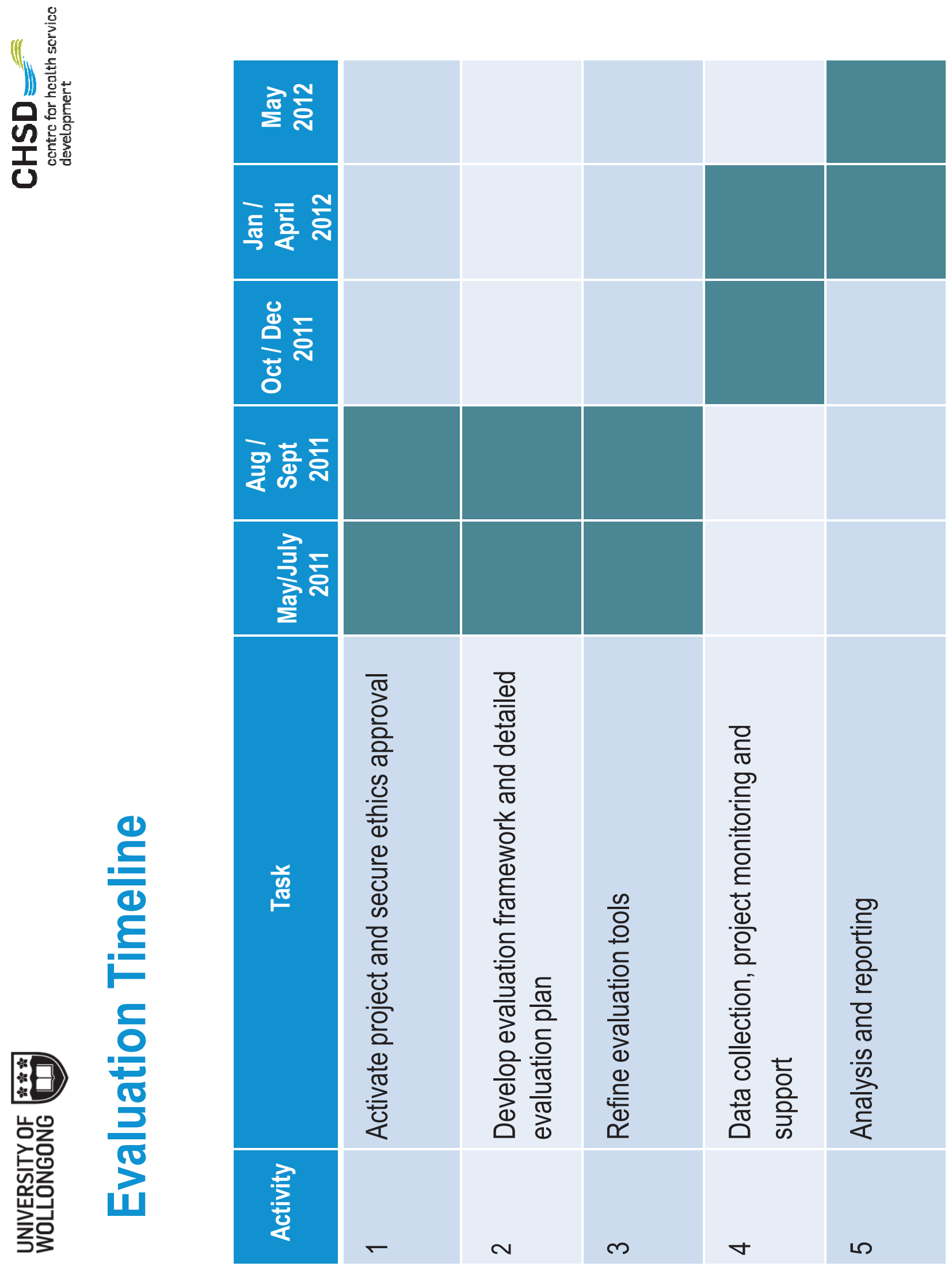

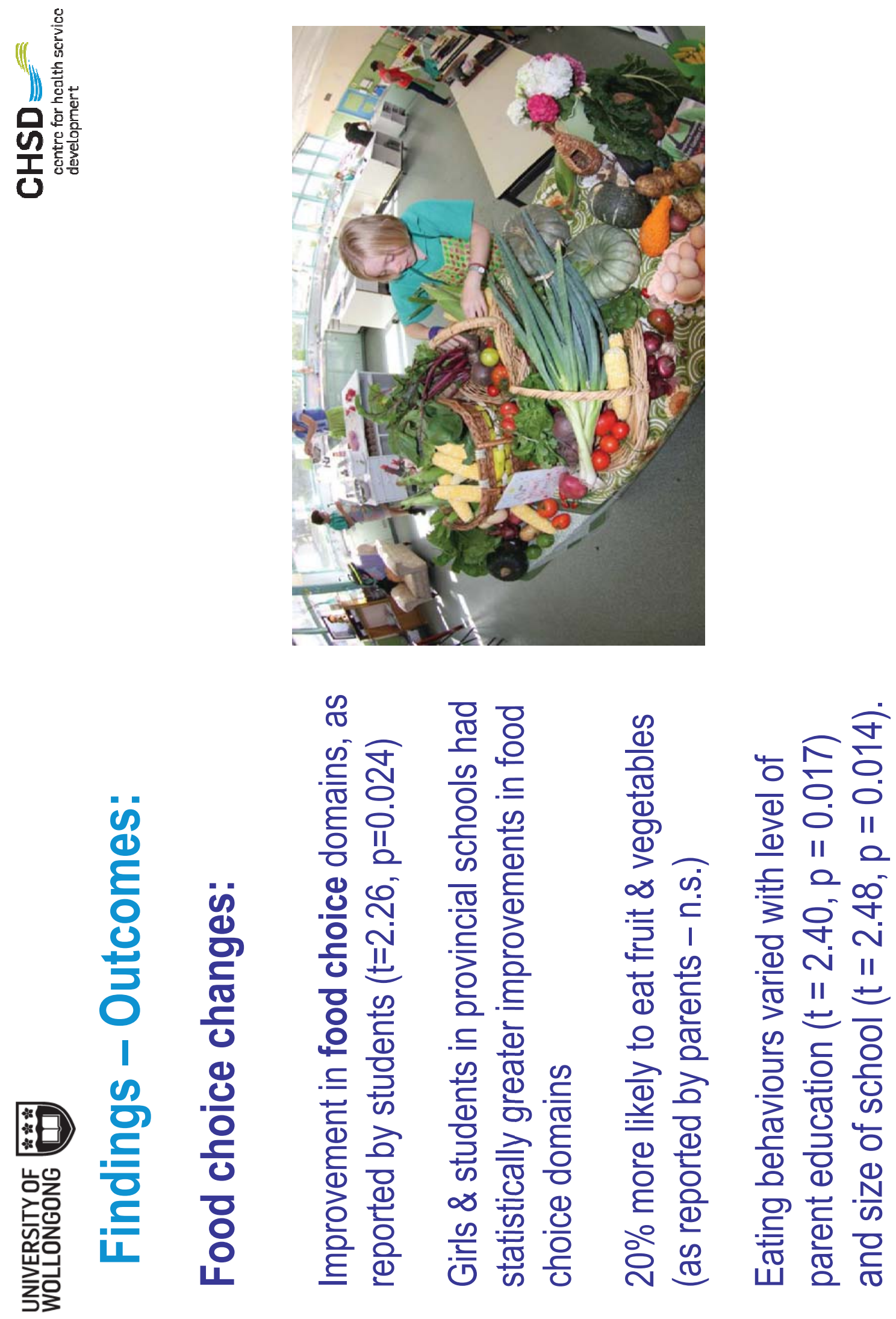


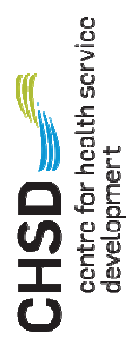

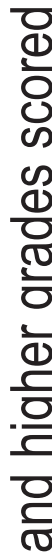

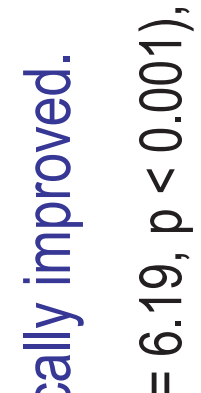

है 本

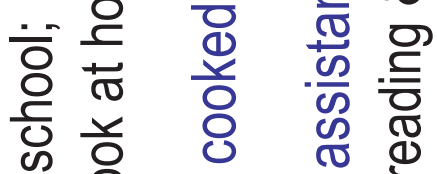

*

ชิ

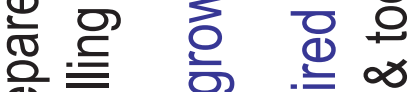

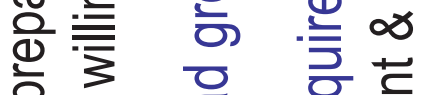

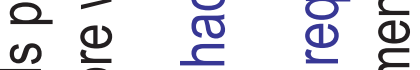

응 으 흐 을 을

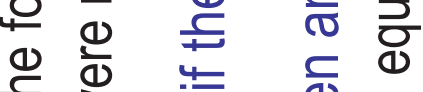

里

(1) ते के के

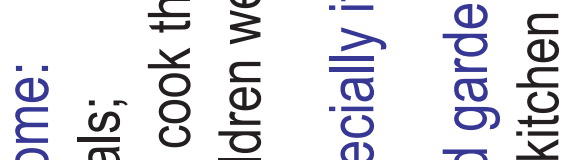

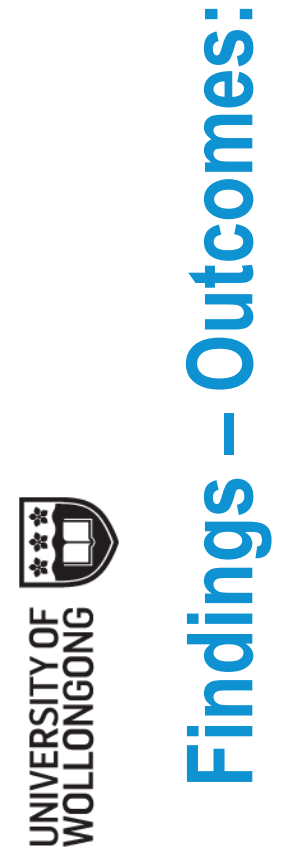

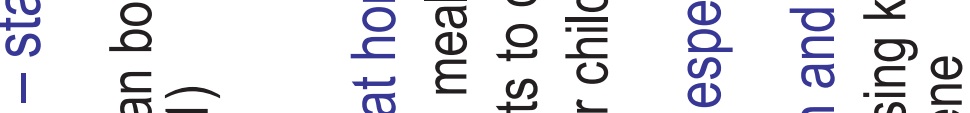

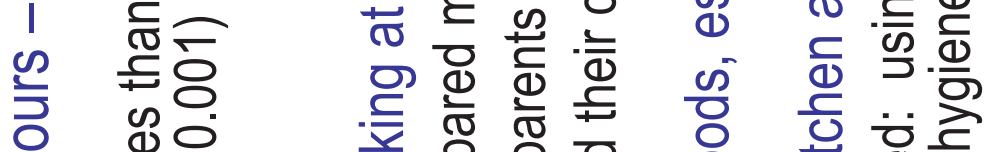

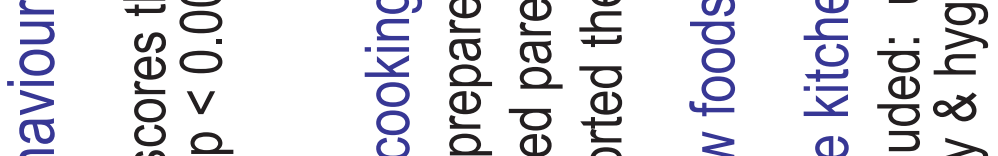

बั

단

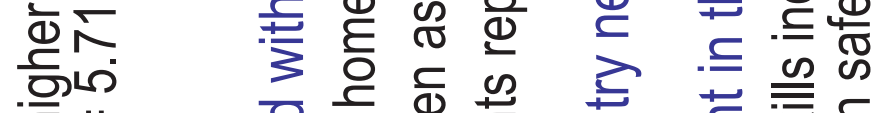

(1) 而

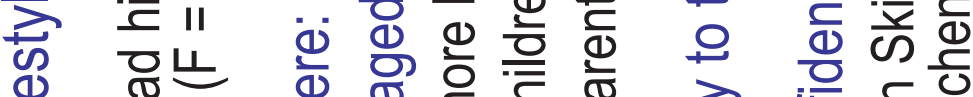

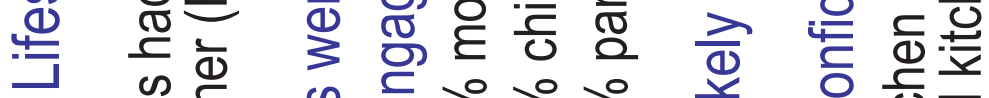

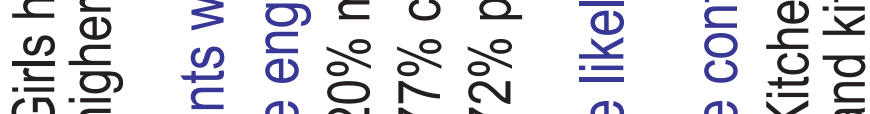

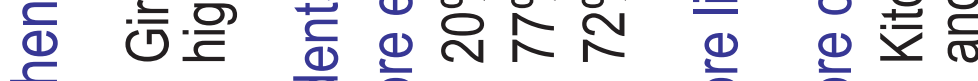

壳・ 竞 

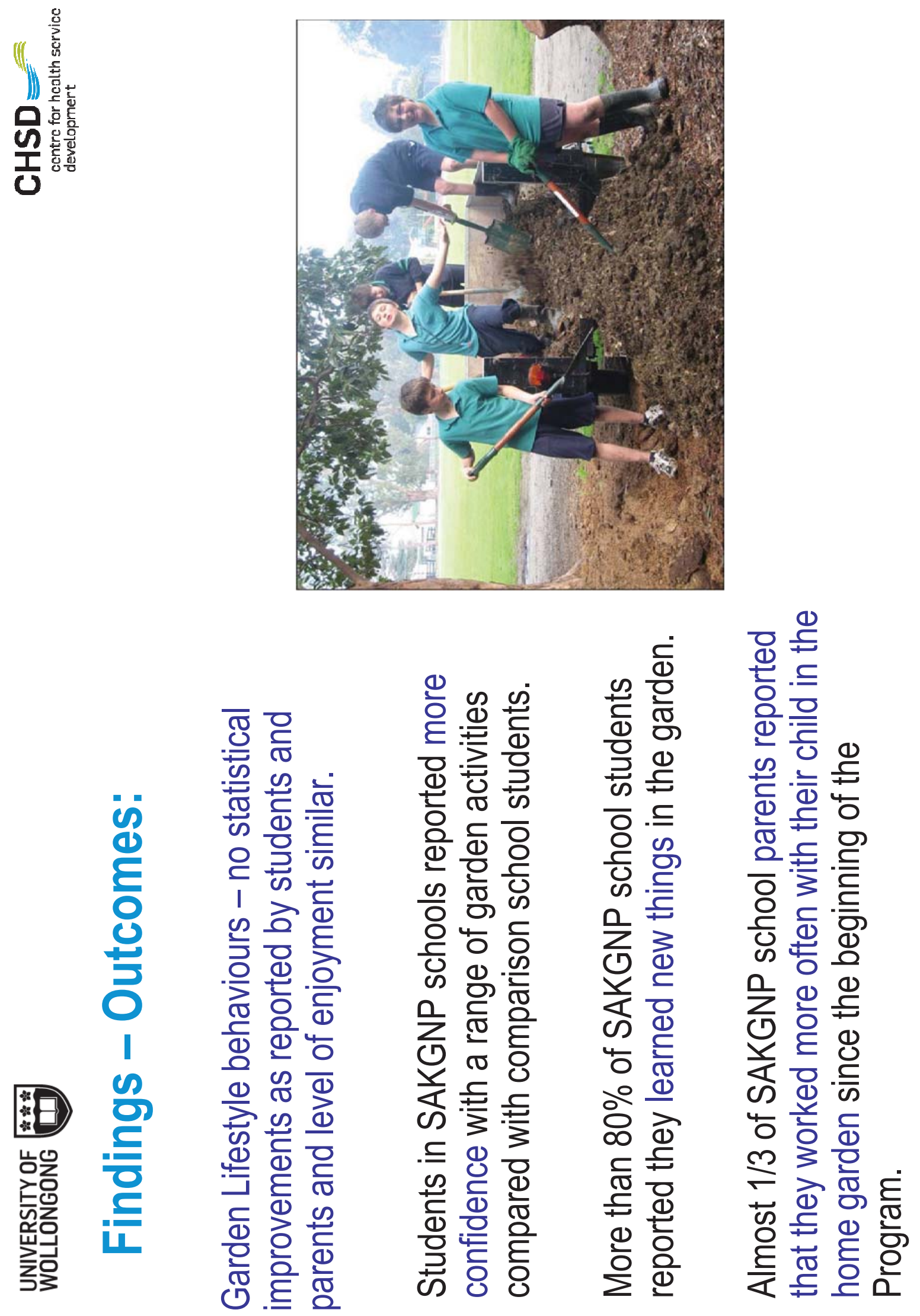

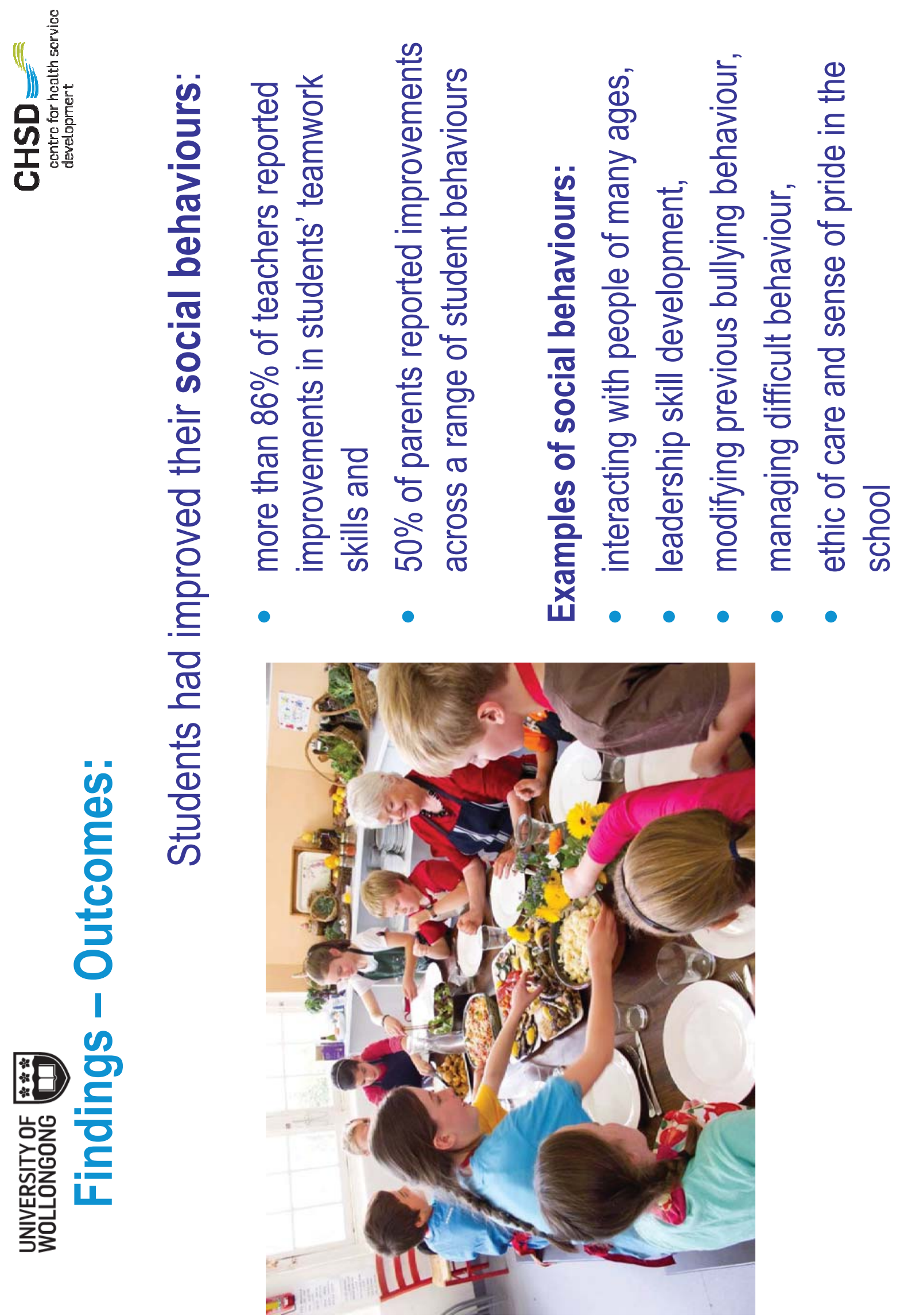

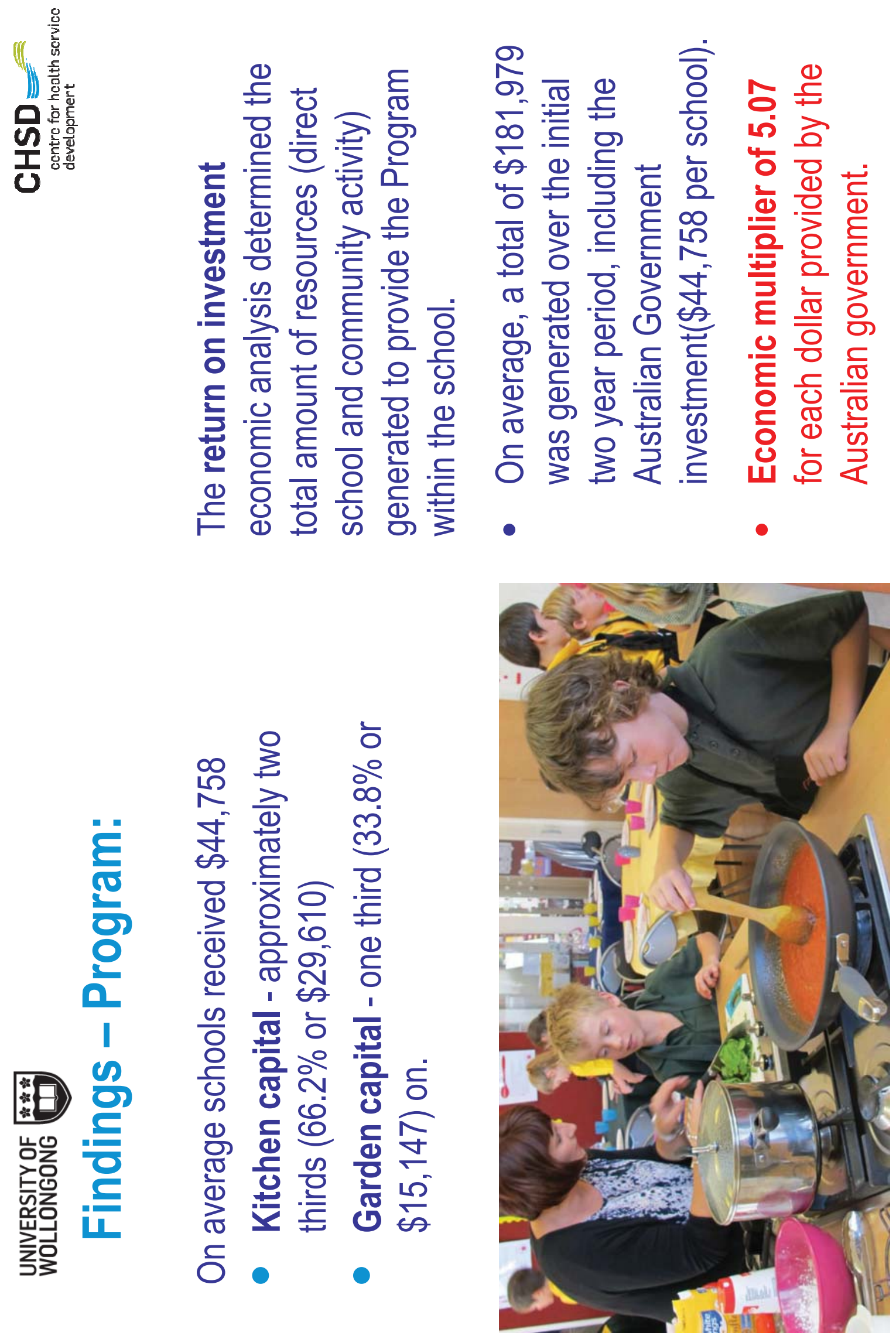

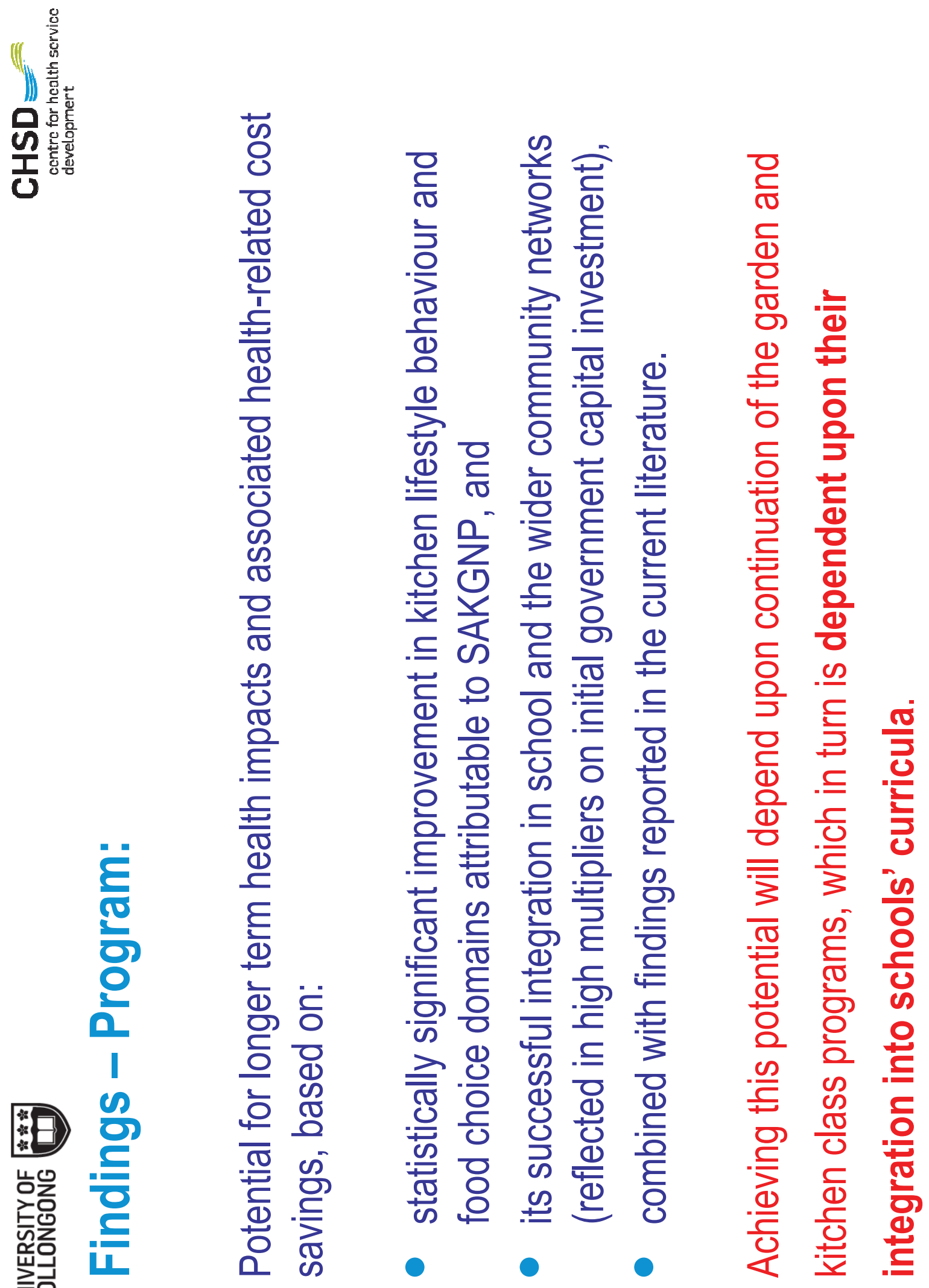

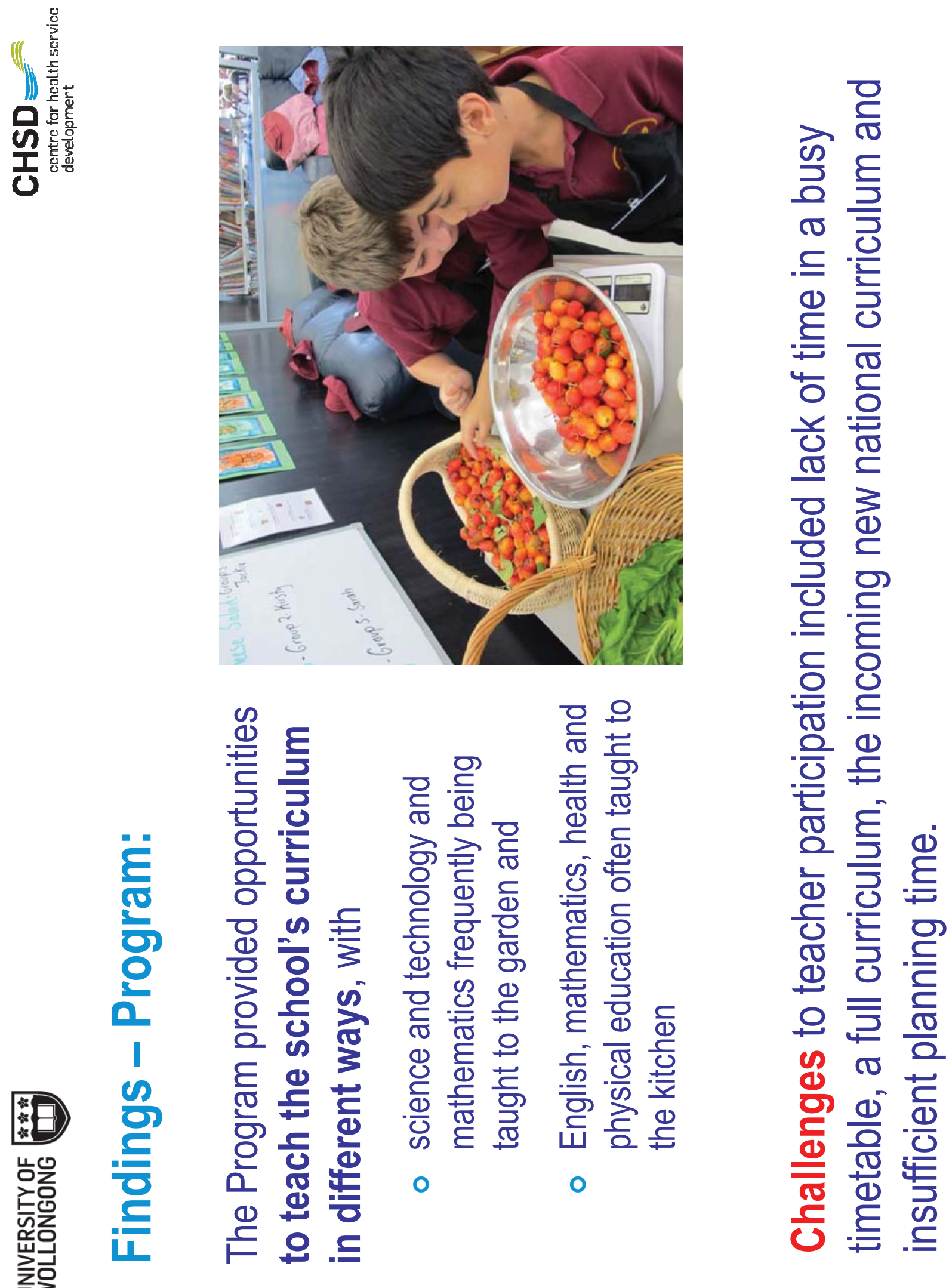



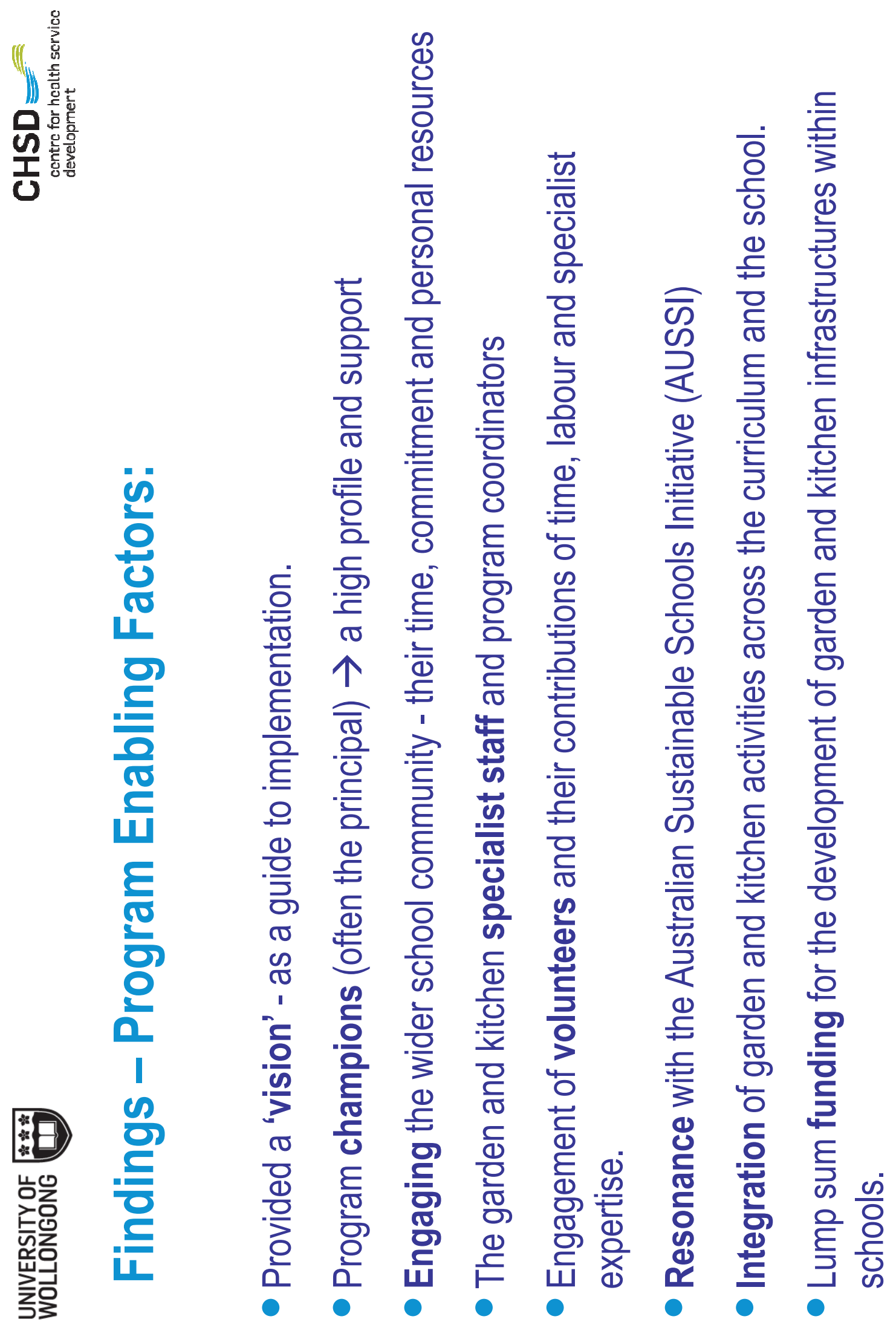


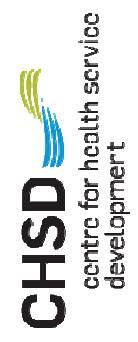

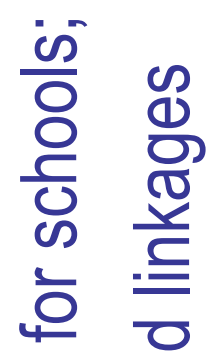

응 능

$\frac{\frac{10}{\pi}}{\frac{0}{0}}$

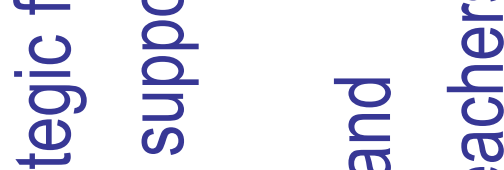

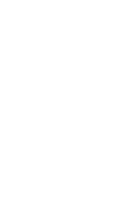

은

त्र

क

들 음

지 언

过 类

을 है

으 응

نं है

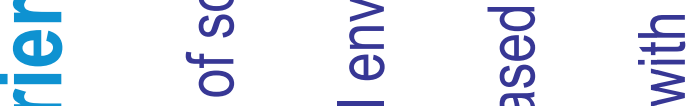

는 귱 유 ह

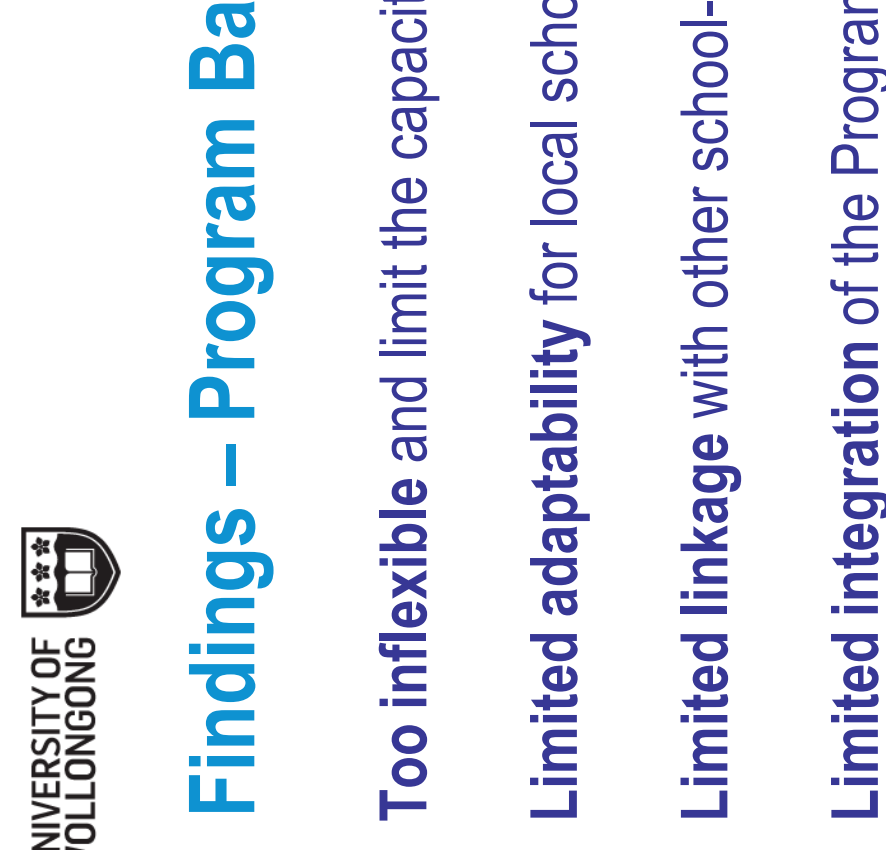

을 음

음

잉은 은

인 夏

.

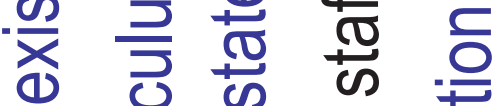

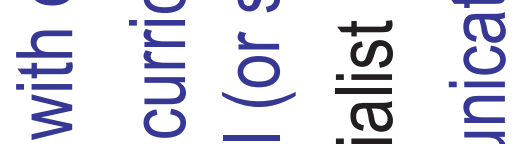

क 4 त $\frac{\pi}{0}$

드 드응 की

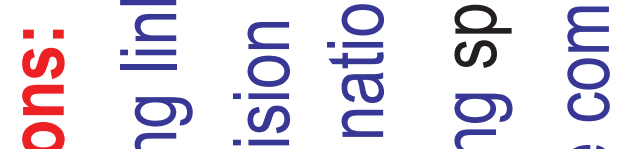

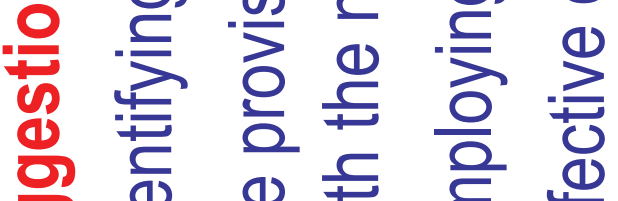

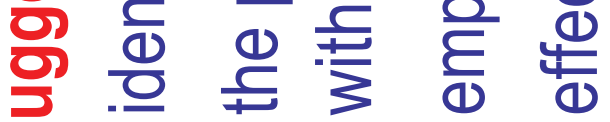

ต

00

○ 0 

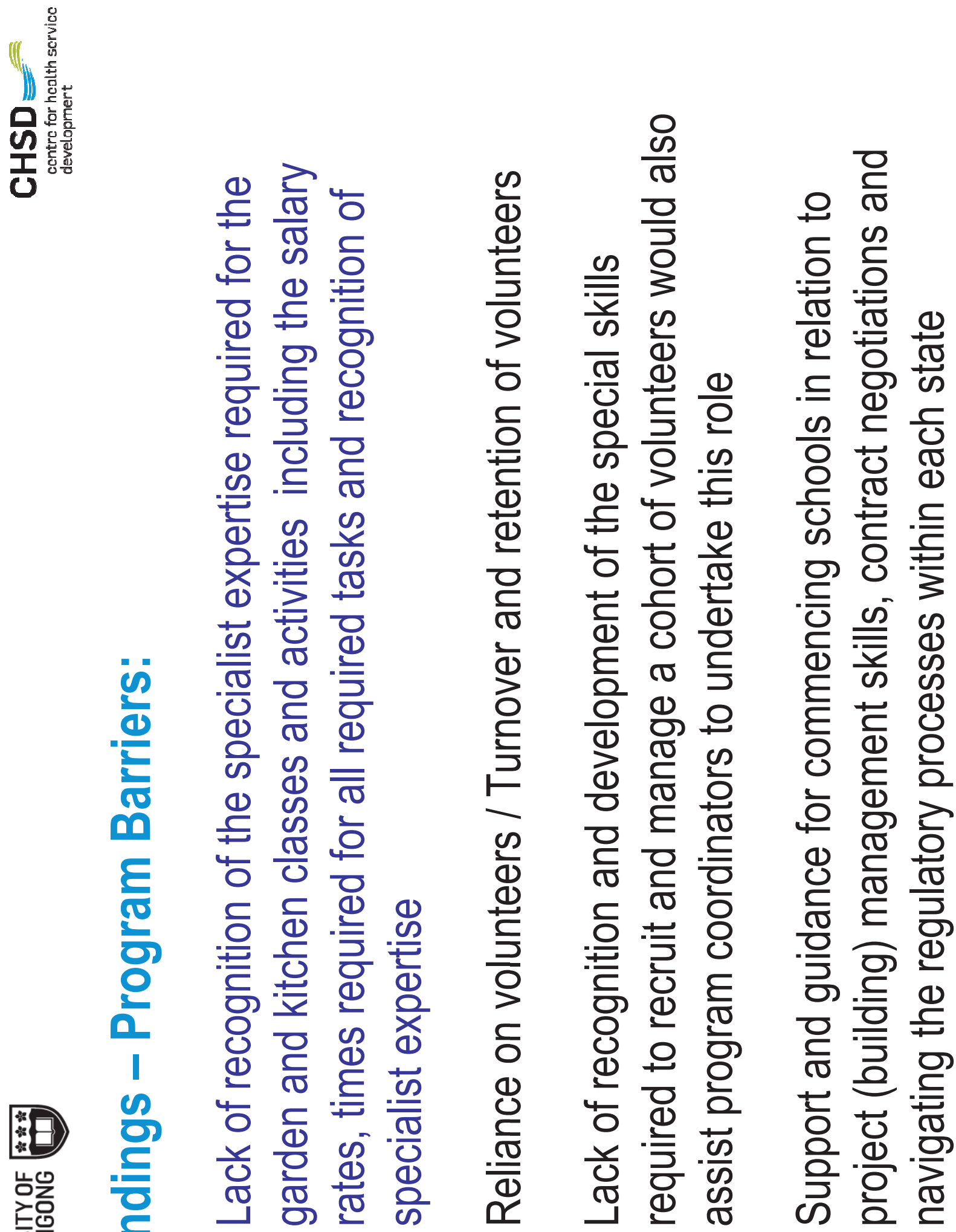

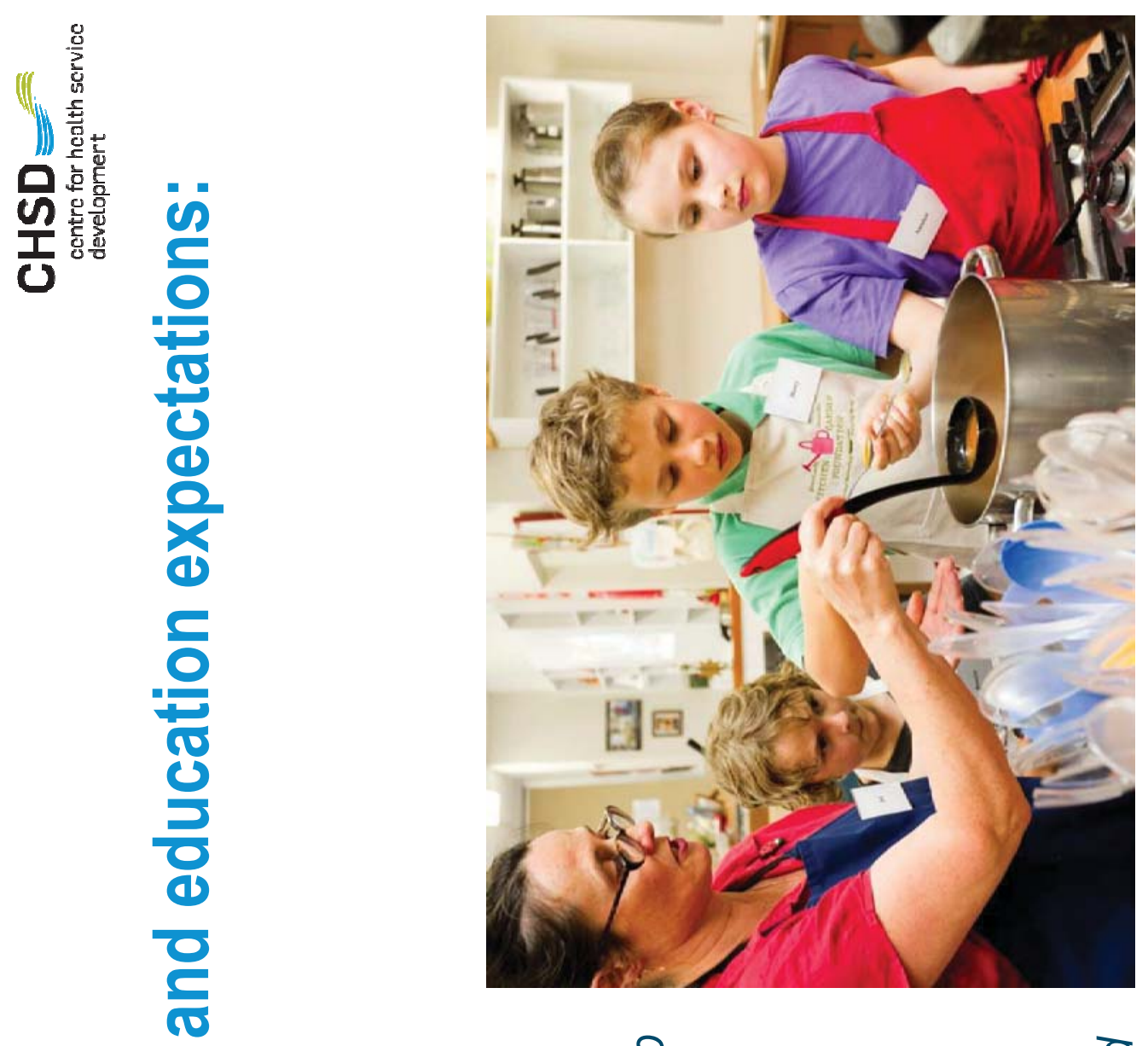

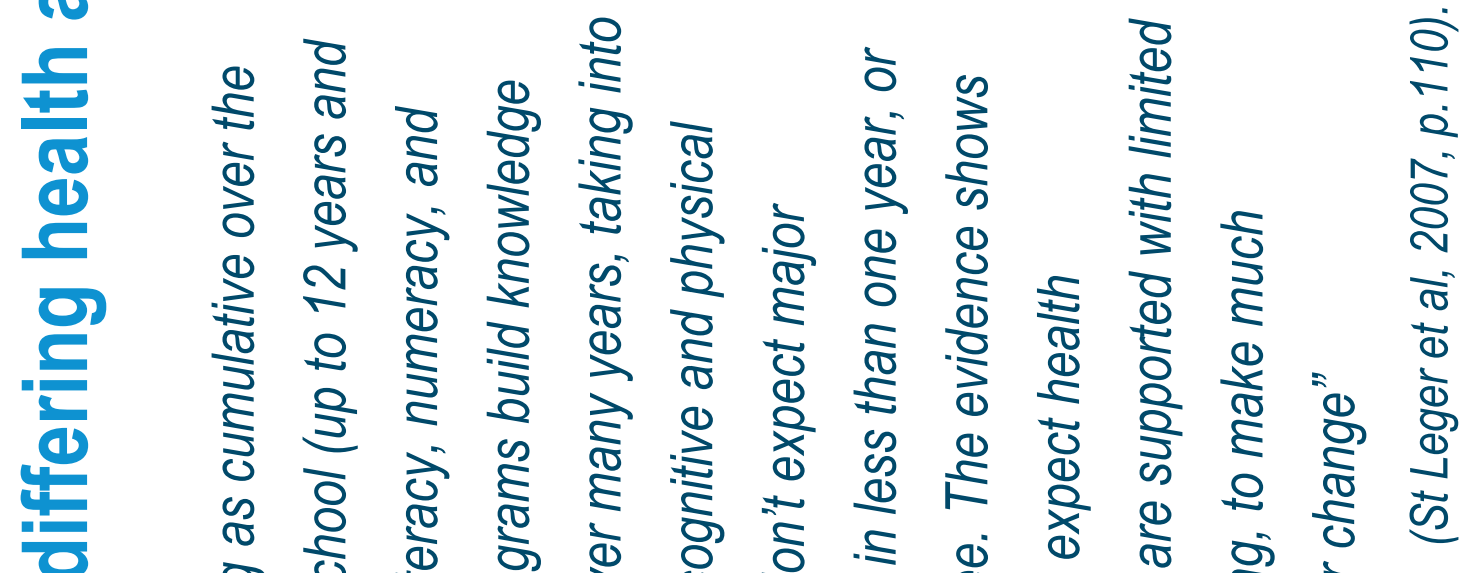

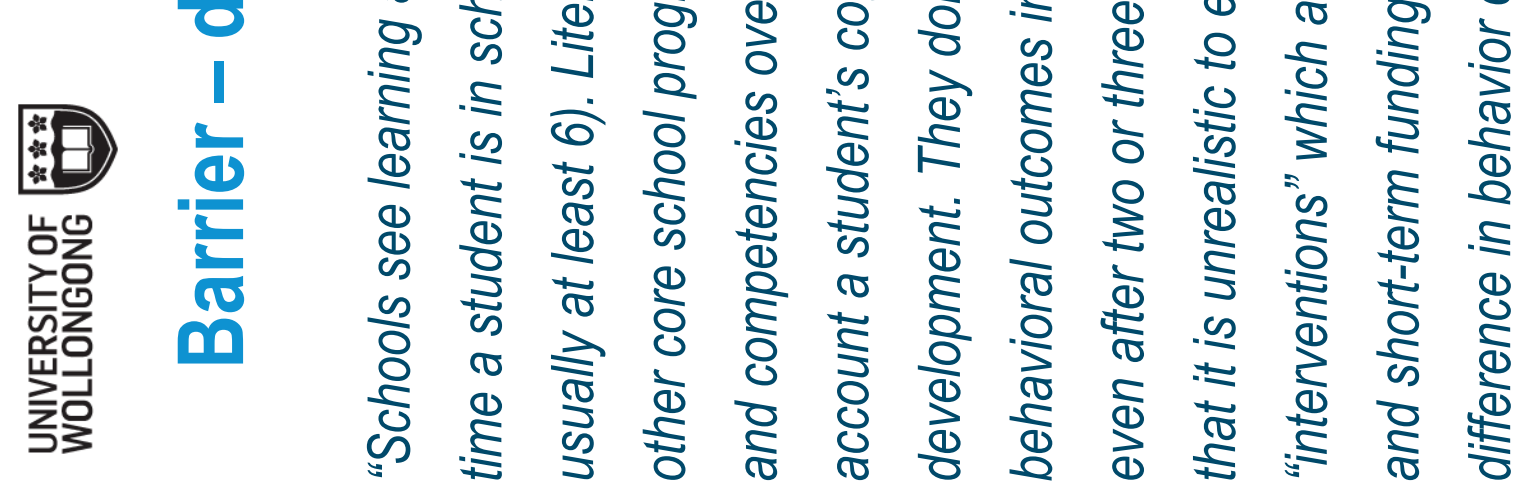



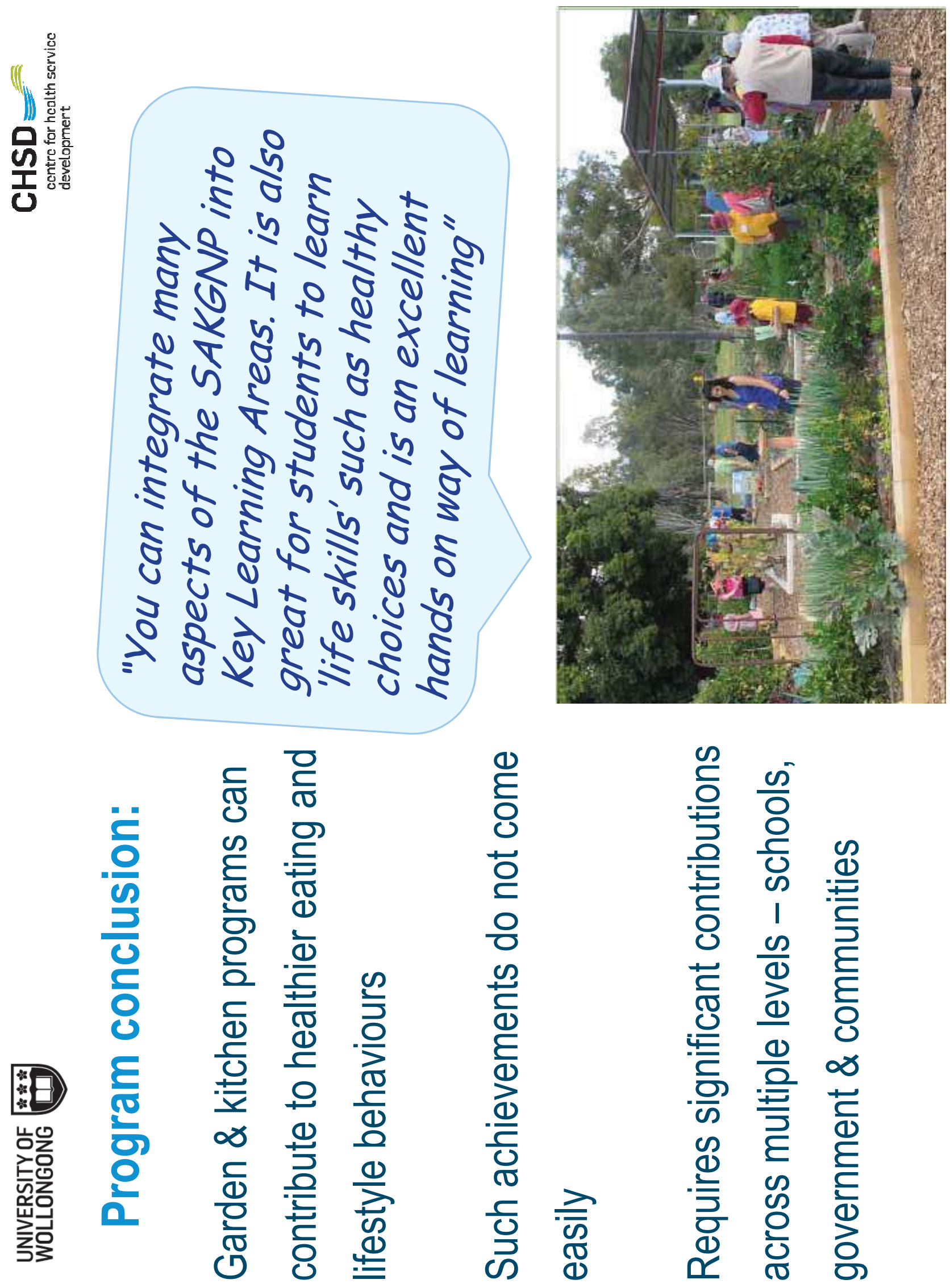

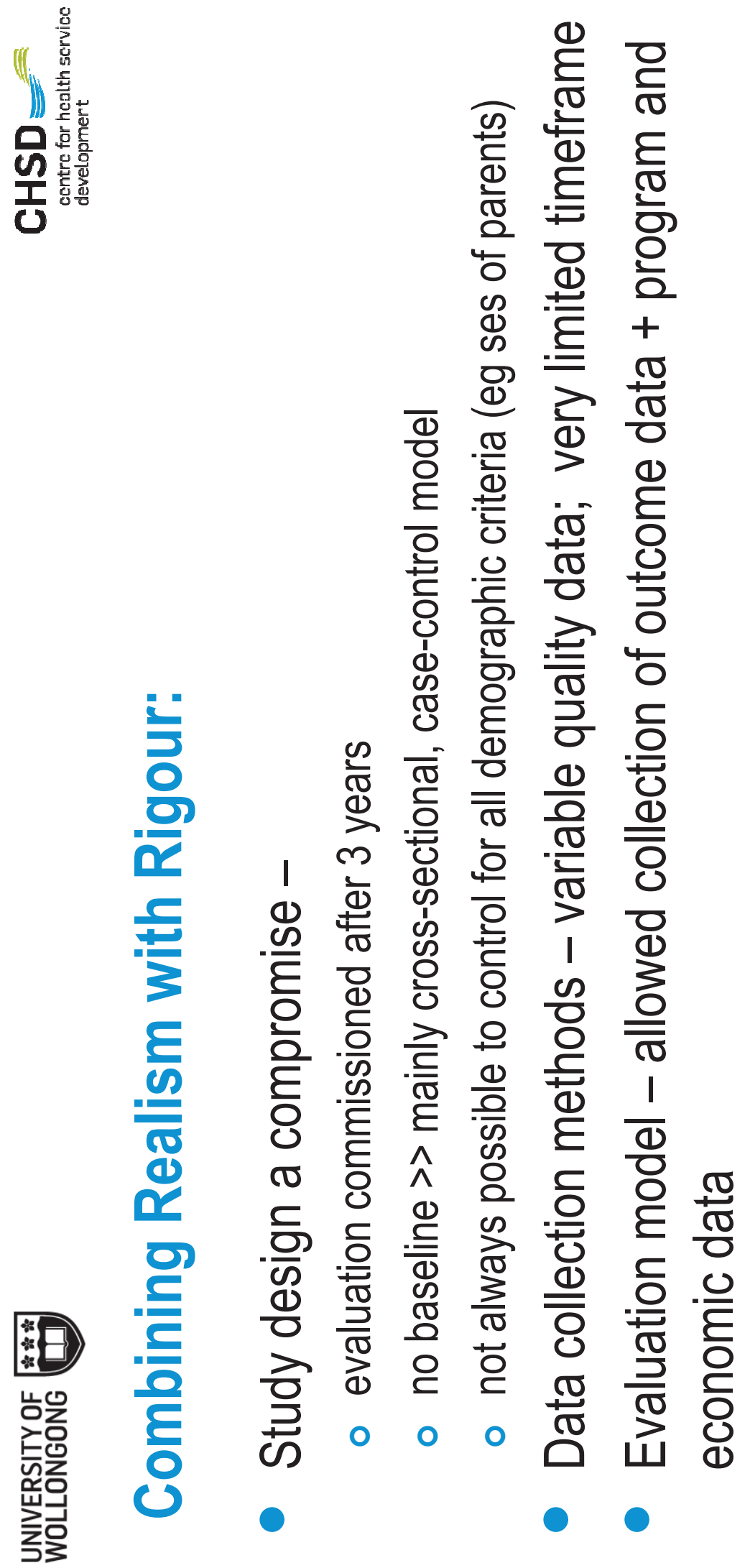

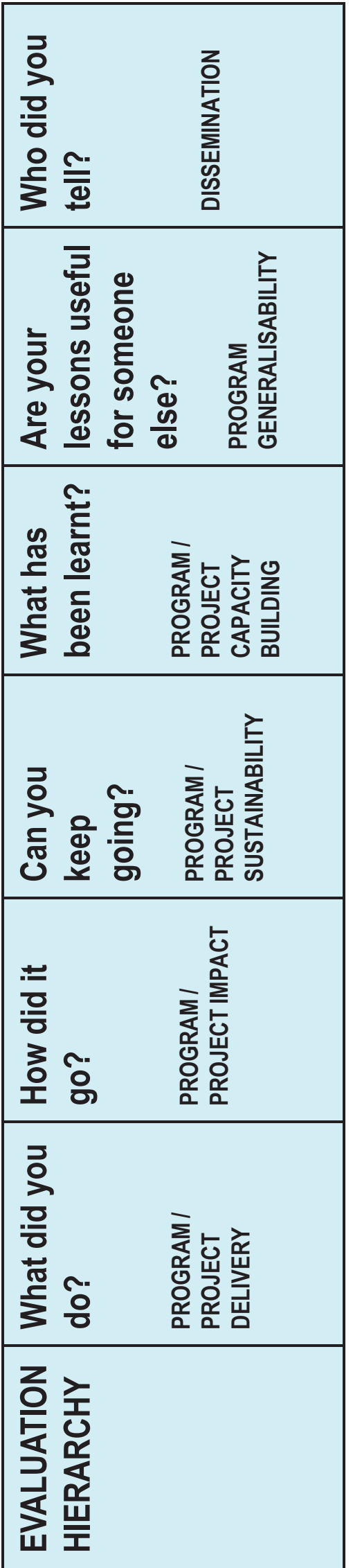



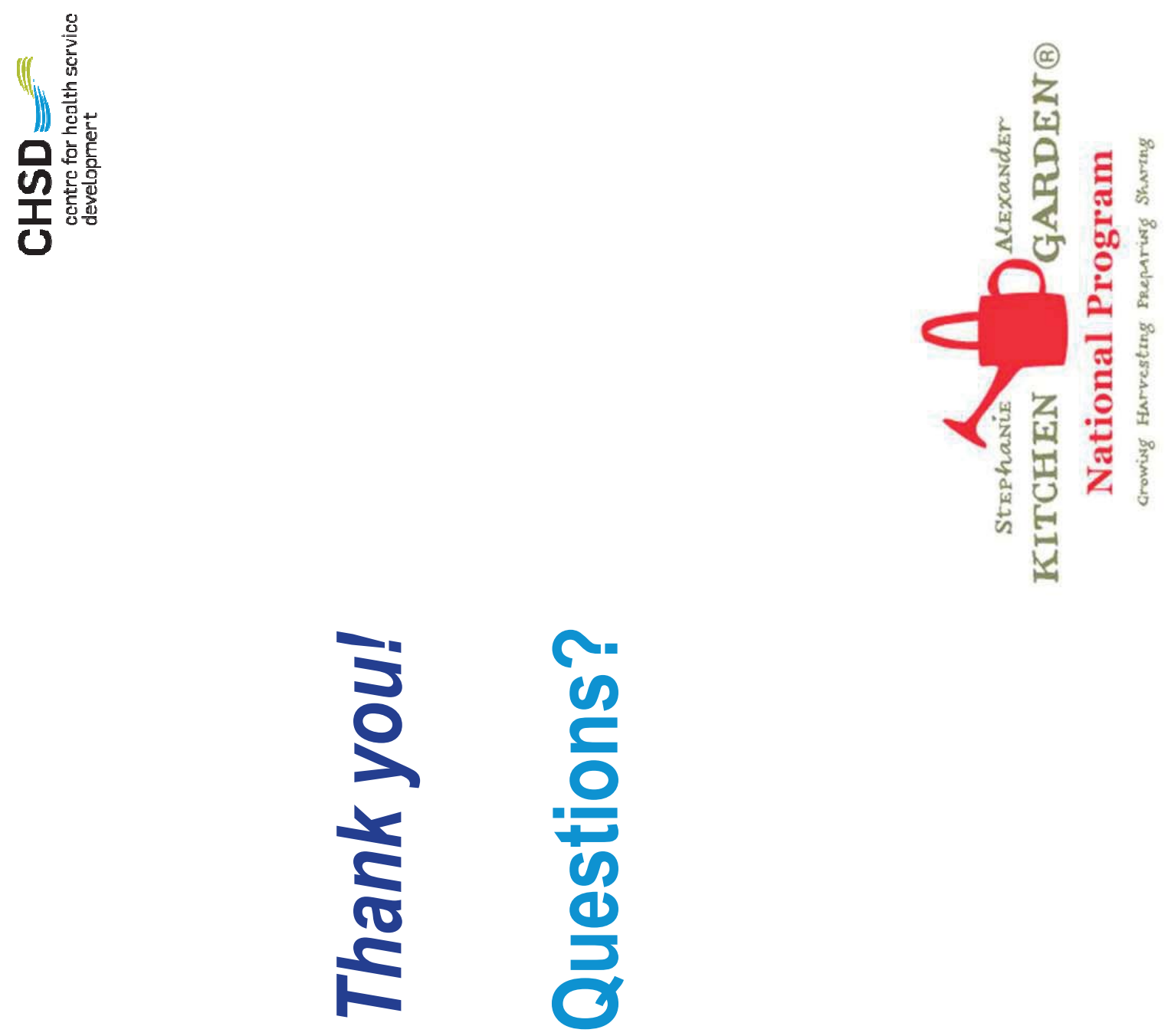

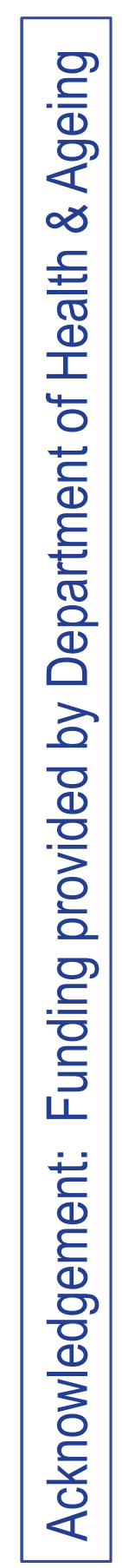

